\title{
Carbonate microfacies and chemostratigraphy of a late Aptian-early Albian marine distal section from the primitive South Atlantic (SE Brazilian continental margin): Record of global ocean-climate changes?
}

\author{
Sergio Caetano-Filho ${ }^{a}{ }^{*}$, Dimas Dias-Brito ${ }^{a}$, René Rodrigues ${ }^{b}$, \\ Ricardo Latgé Milward de Azevedo ${ }^{\mathrm{c}}$ \\ a Centro de Geociências Aplicadas ao Petróleo - UNESPetro, Universidade Estadual Paulista, Rio Claro, SP 13506-900, Brazil \\ ${ }^{\mathrm{b}}$ Faculdade de Geologia, Universidade do Estado do Rio de Janeiro, Rio de Janeiro, RJ 20550-900, Brazil \\ ${ }^{\mathrm{c}}$ Retired from PETROBRAS, Rio de Janeiro, RJ, Brazil
}

\section{A R T I C L E I N F O}

Article history:

Received 10 April 2016

Received in revised form

21 December 2016

Accepted in revised form 11 February 2017

Available online 14 February 2017

\section{Keywords:}

OAE 1b

Aptian

Albian

Sr-isotope stratigraphy

C-isotope stratigraphy

\begin{abstract}
A B S T R A C T
Late Aptian-early Albian limestones from the eastern Brazilian continental margin record the early evolution of the South Atlantic Ocean. In Tethyan and North Atlantic domains, a planktic foraminiferal turnover and organic-rich deposits related to Oceanic Anoxic Event 1b (OAE 1b) point to major oceanclimate changes through this interval. Coeval organic-rich deposits of the South Atlantic Ocean have been interpreted as the product of restricted circulation rather than attributed to a global event. However, previous investigations of the early marine phase of South Atlantic lack data from more distal facies, making correlations to global events difficult. Here, we present $\mathrm{C}, \mathrm{O}$, and $\mathrm{Sr}$ isotopes, elemental geochemistry, TOC and pyrolysis data, as well as a microfacies analysis of an upper Aptian-lower Albian distal section from the Campos Basin (southeastern Brazil). Our focus is on the paleoenvironmental characterization of and the possible association between organic-rich deposits and major perturbations related to Aptian-Albian transition. Five microfacies associations (MA) were identified in the informal units I and III, which were deposited in the neritic region on a carbonate ramp. Organic-rich deposits were described in unit III, composed of planktic-dominated wackestones interbedded with black shales, in a distal dysoxic to anoxic environment. The carbonates ${ }^{87} \mathrm{Sr} /{ }^{86} \mathrm{Sr}$ ratios showed a drastic increase (0.7072-0.7074), interpreted as enhanced chemical weathering, supported by the increase of continental input to the top of section. This trend was accompanied by a long-term $\delta^{13} \mathrm{C}_{\text {carb }}$ negative excursion, which were assigned to the latest late Aptian-early Albian interval of the isotope reference curves, in accordance with the described occurrence of Colomiella recta. This scenario matches those proposed for the late Aptian-early Albian transition and OAE 1b set, as an enhanced greenhouse stage, pointing to the influence of the referred ocean-climate changes on the deposition of organic-rich deposits of the early South Atlantic Ocean. This investigation gives more evidences that these perturbations were a widespread event, as a product of broad-scale disturbances in the global carbon cycle which also controlled organic deposition and preservation on restricted settings.
\end{abstract}

(c) 2017 Elsevier Ltd. All rights reserved.

\section{Introduction}

The early marine phase of the South Atlantic Ocean is represented by carbonate rocks deposited on an extensive Aptian-Albian

\footnotetext{
* Corresponding author.

E-mail addresses: sergio.fcaetano@gmail.com (S. Caetano-Filho), dimasdb@rc unesp.br (D. Dias-Brito), rene@uerj.br (R. Rodrigues), ricardolatge@gmail.com (R.L.M. Azevedo)
}

ramp, in the area that extended northward from the São PauloWalvis Ridge (Dias-Brito and Azevedo, 1986; Spadini et al., 1988; Koutsoukos et al., 1991). This nascent and restricted sea, originated as a result of the Gondwana breakup and the consequent rifting to form the South Atlantic Ocean, is referred by some authors as the central South Atlantic (Fig. 1; e.g. Azevedo, 2004). Fossil content present in these rocks point to marine incursions from the Tethyan Realm initiating in the early-late Aptian (Bengtson et al., 


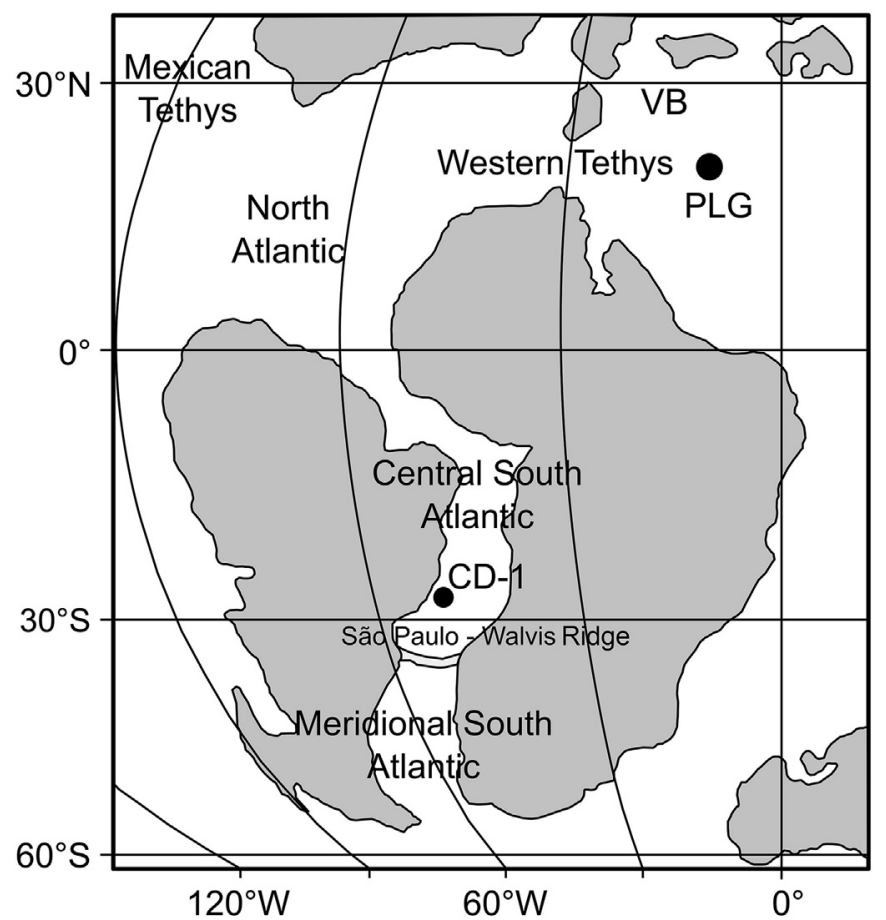

Fig. 1. Paleogeographic map of the Aptian-Albian ( 113 Ma), modified from Sabatino et al. (2015). The central South Atlantic was limited by São Paulo-Walvis Ridge in the south (e.g. Azevedo, 2004). VB: Vocontian Basin; PLG: Poggio le Guaine section; CD-1: studied section.

2007), with some similarities to the global events associated with the Aptian-Albian transition (Bolli et al., 1978; Caron, 1978; Herbin et al., 1987; Magniez-Jannin and Muller, 1987; Koutsoukos et al., 1991; Kochhann et al., 2013).

In Tethyan and North Atlantic pelagic sections, this interval is characterized by bioevents associated with organic-rich horizons of the Oceanic Anoxic Event 1b (OAE 1b), representing drastic changes in Earth's ocean-climate system (Erbacher et al., 1999, 2001; Herrle et al., 2004, 2015; Föllmi et al., 2006; Gale et al., 2011; Huber and Leckie, 2011; Huber et al., 2011; TrabuchoAlexandre et al., 2011; Petrizzo et al., 2012; Coccioni et al., 2014; Kennedy et al., 2014; Sabatino et al., 2015). Compared to other Cretaceous anoxic events, OAE $1 \mathrm{~b}$ is a complex set of organic-rich intervals, including Jacob, Kilian, Paquier/Urbino and Leenhardt horizons, that likely represent long-term enhanced conditions for organic-matter preservation (e.g. Erbacher et al., 1999, 2001; Leckie et al., 2002; Föllmi et al., 2006; Coccioni et al., 2014; Sabatino et al., 2015). Although the mechanisms driving oceanic anoxic events are still debated, recent studies have interpreted these paleoceanographic changes as a result from a pronounced greenhouse climate and subsequent higher continental weathering rates and nutrient influxes to basins (Erbacher et al., 1999; Jones and Jenkyns, 2001; Jenkyns, 2010; Bodin et al., 2015; Sabatino et al., 2015). Consequently, increased bioproductivity and dysoxic-anoxic conditions were developed which favoured organic-matter preservation (Jenkyns, 2010). In this scenario, the progressive organic carbon burial and enhanced continental weathering led to a decrease of $\mathrm{CO}_{2}$ in the atmosphere, promoting the global cooling. These global climate perturbations were recorded as organic-rich deposits and documented by a rapid increase in ${ }^{87} \mathrm{Sr} /{ }^{86} \mathrm{Sr}$ ratios $(\sim 0.7072-0.7074)$ through the Aptian-Albian transition (Bralower et al., 1997; Jones and Jenkyns,
2001; Bodin et al., 2015). Recent studies have assigned the Aptian-Albian boundary to foraminiferal bioevents (extinctions and morphological change) coincident with the Kilian level of OAE $1 \mathrm{~b}$, at the end of a $\delta^{13} \mathrm{C}$ negative excursion (Petrizzo et al., 2012; Kennedy et al., 2014; Sabatino et al., 2015).

The oldest marine deposits of the central South Atlantic were dated to earliest-late Aptian and suggested surface-water connection between this restricted sea and the North Atlantic, as reconstructed using ammonites and planktic foraminiferal assemblages retrieved from the lower-upper Aptian sedimentary record of the Sergipe Basin, northeast Brazilian margin (Koutsoukos et al. 1991; Bengtson et al., 2007). Moreover, the connection to the North Atlantic in several basins of the central South Atlantic during the late Aptian-early Albian can be deduced from other fossil evidence, such as pithonellids and colomiellids (e.g., Chevalier and Fischer, 1982; Moullade and Guérin, 1982; Dias-Brito, 1994, 1999, 2000; Carvalho et al., 1999; Dias-Brito and Ferré, 2001). Recently, Kochhann et al. (2013) re-examined planktic foraminiferal assemblages from the lowermost interval of the DSDP 364 site in the Kwanza Basin and recognized bioevents related to planktic foraminiferal turnover associated with the late Aptian-early Albian transition (Petrizzo et al., 2012; Kennedy et al., 2014).

Organic-rich deposits were also identified in this interval from the Sergipe (NE Brazilian margin) and Kwanza (Angola margin) basins, and Falkland Plateau, suggesting that dysoxic-anoxic conditions prevailed in bottom water during the early marine stage of the South Atlantic (Bolli et al., 1978; Herbin et al., 1987; MagniezJannin and Muller, 1987; Koutsoukos et al., 1991; Hart and Koutsoukos, 2015). The general interpretation is that these conditions were primarily the results of restricted circulation patterns, such as those associated with the "silled basin" model (Koutsoukos et al., 1991; Hart and Koutsoukos, 2015). In the southeast Brazilian continental margin, the data published so far did not report the upper Aptian-lower Albian organic-rich interval described in other South Atlantic sites, possibly related to a more proximal position of these sections in the carbonate platform (data from petroleum wells drilled under shallow-water depths) or even deposited in a different time-interval (Dias-Brito and Azevedo, 1986; Esteves et al., 1987; Koutsoukos and Dias-Brito, 1987; Dias-Brito, 1987, 1994, 1995, 1999, 2000, 2002; Azevedo et al., 1987a,b; Spadini et al., 1988; Carvalho et al., 1999; Dias-Brito and Ferré, 2001; Okubo et al., 2015; Favoreto et al., 2016).

Therefore, in the present study we investigated an upper Aptian-lower Albian distal section from the southeastern Brazilian margin corresponding to an intercalation of organic-rich limestones and shales of the Macaé Group, in the Campos Basin. The section was crossed by an exploration well drilled in deep waters (close to $3000 \mathrm{~m}$ water column depth) and corresponds to early marine deposits immediately above the top of the evaporite layer (transitional lacustrine-marine phase), overlain by more than $5000 \mathrm{~m}$ of "post-salt" marine deposits. The primary goal was to reconstruct the distal paleoenvironments of the early marine South Atlantic based on microfacies analysis and chemostratigraphy $\left(\delta^{13} \mathrm{C},{ }^{87} \mathrm{Sr} /{ }^{86} \mathrm{Sr}\right.$, TOC, pyrolysis, and elemental geochemistry). Furthermore, considering that climate changes through the Aptian-Albian transition were associated with global carbon cycle perturbations, this study is also a contribution on the discussion about the relationship between the early marine South Atlantic deposits and the coeval global events. The data present here is an unprecedented opportunity to investigate the distal facies of primitive South Atlantic (late Aptian-early Albian), represented by deposits buried by thousands of meters of rock thickness under deep waters of Brazilian continental margin. 


\section{Geological setting}

\subsection{The eastern Brazilian continental margin and Campos Basin}

The Campos Basin is part of a set of basins located along the eastern Brazilian continental margin, which extends from the Pelotas Basin in the south to the Pernambuco-Paraíba Basin in the north. The genesis of these basins was associated with the Gondwana breakup and the subsequent South Atlantic Ocean opening, initiated in the Late Jurassic. Consequently, all the basins that compose the eastern Brazilian continental margin are related to a distensional tectonic model, with their stratigraphic record divided into three tectono-stratigraphic phases (Ojeda, 1982; Chang and Kowsmann, 1987; Ponte and Asmus, 2004): (i) continental clastic, deposited in a continental rift setting (Late Jurassic-Early Cretaceous); (ii) transitional evaporitic, related to a lacustrine, hypersaline restricted setting (Aptian), characterized by extensive evaporitic deposition; and (iii) marine, in a drift tectonic setting and ocean floor spreading, from an early restricted marine phase (Aptian-Albian; Dias-Brito and Azevedo, 1986; Dias-Brito, 1987; Spadini et al., 1988; Koutsoukos et al., 1991; Bengtson et al., 2007) to open marine-oceanic conditions (Cenomanian to Recent).

Winter et al. (2007) presented the most recent reconstruction of the Campos Basin stratigraphy calibrated against the Gradstein et al.'s (2004) Time Scale. These authors proposed three supersequences, representing the tectono-stratigraphic intervals presented above. The "Rift Supersequence" starts with flood basalts of the Cabiúnas Formation (Hauterivian), followed by a clastic (Itabapoana and Atafona formations - Barremian) and lacustrine bioclastic carbonate deposits (Coqueiros Formation-Early Aptian). Lacustrine shales and microbial limestones (Gargau and Macabu formations) overlapped by evaporites (Retiro Formation) compose the "Post-Rift Supersequence" (Aptian). Two depositional sequences constitute the "Drift Supersequence", related to the oceanic development of the South Atlantic. From the late Aptian to the Cenomanian, a progressive drowning of a carbonate platform (Quissamã and Outeiro formations, Macaé Group) is registered, culminating in the accumulation of organic-rich shales (Imbetiba Formation). The second depositional sequence comprises progradational-retrogradational stacking patterns from the
Turonian to Recent. They are composed of clastic proximal deposits, shales and marlstones, with local occurrences of bioclastic carbonate rocks (Campos Group).

Microfacies analysis and biostratigraphic studies in the eastern Brazilian marginal basins (Sergipe-Alagoas, Jequitinhonha, Campos and Santos basins) revealed Tethyan influence in the earliest marine phases of the South Atlantic Ocean, documented by colomiellids, pithonellids, nannoconids, stemless crinoids (roveacrinids and saccocomids), planktic foraminifera (Koutsoukos, 1992; Carvalho et al., 1999; Dias-Brito, 2000; Dias-Brito and Ferré, 2001), and ammonites (Bengtson et al., 2007). Consequently, the central South Atlantic is regarded as a segment of the North Atlantic, as a long and narrow arm of the Tethyan domain (a paratethyan tropical gulf; Dias-Brito, 2000), lacking coral and rudist reefs and some characteristic large foraminifera (e.g. orbitolinids; Dias-Brito, 1995, 2000).

\subsection{The Macaé Group carbonate deposition in Campos Basin (late Aptian-Albian)}

The studied section corresponds to the base of the Macaé Group (Fig. 2) in a distal area of the basin, deposited directly above the evaporites of the Retiro Formation (transitional phase). Carbonate deposits of the lower Macaé Group encompass oolitic to oncolitic grainstones and packstones associated with shoals, forming shallowing upward cycles on a shallow ramp (Esteves et al., 1987; Guardado et al., 1989) and represents high-to moderate energy limestones within the Quissamã Formation. The base of this sequence shows thick dolomitic layers (Búzios Member) and an increase in clay contents in distal parts of the basin is observed (Winter et al., 2007; Fig. 2). Transgressive pelagic limestones of the Outeiro Formation overlie the Quissamã Formation, and are represented by wackestones, mudstones, and shales (in more distal parts) bearing planktic foraminifera, pithonellids and radiolarians (Dias-Brito and Azevedo, 1986; DiasBrito, 1987). Turbiditic deposits of the Namorado Formation are interbedded in this unit and controlled by halokinesis (Winter et al., 2007). On the top of the Macaé Group, marlstones and organic-rich shales of the Imbetiba Formation represent the drowning of the carbonate platform and incursion of oceanic

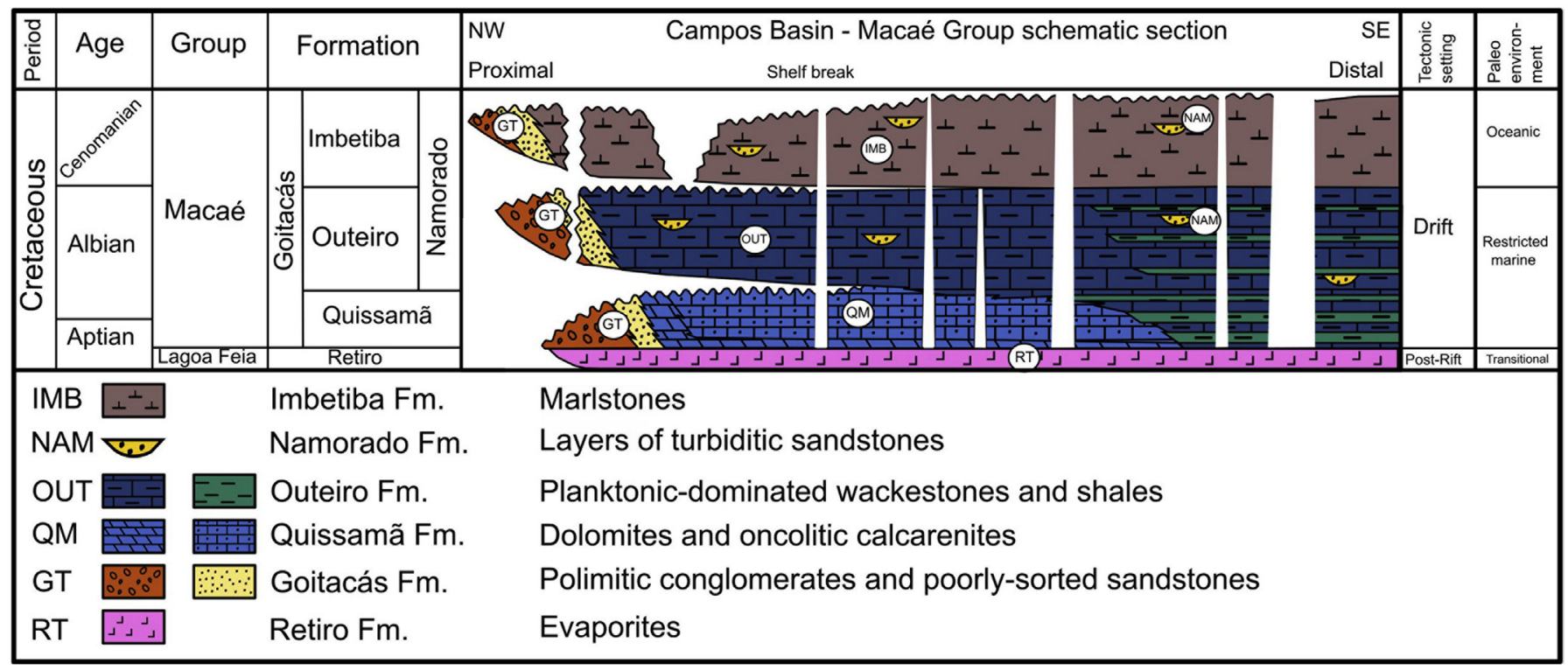

Fig. 2. Macaé Group's stratigraphic chart, Campos Basin, after Winter et al. (2007). 
waters during the Cenomanian (Dias-Brito and Azevedo, 1986; Spadini et al., 1988).

In terms of paleoceanography and paleoecology, the carbonate deposition of the Quissamã and Outeiro formations corresponded to the initial phase of the "pre-oceanic phase" (Dias-Brito and Azevedo, 1986), due to the interpretation of inefficient connection with coeval oceans resulting in a restricted circulation pattern (Koutsoukos et al., 1991; Azevedo, 2004). These interpretations come from the biotic content of this interval, which is characterized by low diversities of benthic and planktic organisms associated with a shallow neritic and hypersaline environment, under warm and dry weather conditions (Dias-Brito and Azevedo, 1986; DiasBrito, 1987). At the end of Outeiro Formation deposition the estimated paleobathymetry was no greater than $200 \mathrm{~m}$ deep (Koutsoukos and Dias-Brito, 1987).

Only a few studies focused on the biostratigraphy of the Macaé Group, which defined low-resolution local biozones (Tröelsen and Quadros, 1971; Schaller, 1973; Azevedo et al., 1987b; Antunes, 1996). Azevedo et al. (1987b) presented a foraminiferal biozonation for the carbonate Albian platform. From base to the top, they recognized the following biostratigraphic intervals: a) the informal biozone Trocholina sp., which was defined as the local occurrence of this taxon in association with Favusella spp; its lower limit was placed on the top of the evaporite layer (Retiro Formation) and ascribed to the early to middle Albian based on the occurrence of the Cyclopsiella sp. (palynomorphs); b) the Favusella washitensis zone that ranges between the last occurrence of the Trocholina sp. and the local extinction of the index taxon in the middle to late Albian, below the occurrence of Ticinella; c) on the top of the sequence, the Ticinella raynaudi zone ranges to the extinction of T. raynaudi and T. primula, pointing to the end of the Albian. On the other hand, the Nannoconus truitti nannofossil zone (Tröelsen and Quadros, 1971; Schaller, 1973) marks the Albian interval, with the upper limit coinciding with the top of $T$. raynaudi biozone (Azevedo et al., 1987b; Antunes, 1996). Azevedo et al. (1987b) and Viviers and Azevedo (1988) repositioned the Nannoconus extinction close to the top of the Albian, associated with the last occurrences of the foraminifers $T$. raynaudi, T. primula, Rotalipora ticinensis and Neobulimina minima, as well as the dinoflagellate Oligosphaeridium complex.

Recently, Kochhann et al. (2013) identified the following foraminifers zones in the DSDP 364 site (Kwanza Basin): Hedbergella trocoidea (upper Aptian), Paraticinella eubejaouaensis (Paraticinella rohri, upper Aptian), Microhedbergella rischi (lower Albian) and Pseudothalmanninella ticinensis (upper Albian), registering the foraminiferal turnover events associated with the late Aptian-early Albian transition (Petrizzo et al., 2012; Kennedy et al., 2014) in the South Atlantic. The interval studied by these authors is correlated to the Macaé Group carbonates, based on microfacies content, and the lower part of the core is marked by organic rich-shales interbedded with carbonate rocks (Bolli et al., 1978), similar to the CD-1 section studied herein.

\subsection{Studied section}

The CD- 1 section comprises the interval extending from 5340 to $5652 \mathrm{~m}$ deep of an exploration well drilled in a distal portion of the Campos Basin, southeastern Brazilian continental margin (Fig. 3A). The drilling site is located between two salt domes (Fig. 3B), in a compressive domain of the margin. The lithotypes present are fine-grained limestones and shales of the Quissamã and the Outeiro formations, characteristic of the distal portions of the Macaé Group. Three informal units were described, from base to the top (Fig. 3C).
Unit I (5650-5620 m deep; Fig. 3C) includes mudstones, bioclastic wackestones and packstones with benthic-dominated faunas, corresponding to the Quissamã Formation. The higher gamma ray values towards the top correspond to an increase in clay minerals. This unit lies above the evaporites of the Retiro Formation and its top is marked by the contact with an allochthonous evaporite (anhydrite) layer of unit II (5620-5570 m deep; Fig. 3C). This anhydrite layer is characterized by low gamma ray values, high density $\log$ values $\left(\sim 3 \mathrm{~g} / \mathrm{cm}^{3}\right)$ and low sonic log values. Repetition of evaporite layers has been reported in this distal compressive domain of the margin (e.g. Mohriak, 2004 2009). Unit III (5570-5335 m deep; Fig. 3C) is composed of bioclastic wackestones, mudstones and shales with a plankticdominated biota, associated with the Outeiro Formation. These lithotypes constitute high frequency cycles, as marked by the gamma ray $\log$.

\section{Materials and methods}

A total of 49 samples were provided by Petrobras, which were composed of 19 sidewall samples and 30 cuttings. The cuttings correspond to 3-5 mm-sized fragments representing a $3 \mathrm{~m}$-thick interval. Additionally, geophysical profiles (gamma ray, sonic and density) were used.

\subsection{Petrographic study}

Petrographic studies were performed at labs of the Center for Petroleum Geosciences - UNESPetro, at São Paulo State University. Thin sections were prepared for all the sidewall samples and were examined using a Zeiss Imager A2 optical microscope, with an attached cathodoluminescence device CITL Mk5-2. Cathodoluminescence conditions for limestones analysis were adjusted to $13 \mathrm{kV}$ and $230 \mu \mathrm{A}$, under vacuum conditions of $\sim 0.003 \mathrm{mBar}$. SEM/EDS analyses were made on carbon-coated thin sections utilizing a Zeiss EVO MA15 scanning electron microscope with an attached Bruker XFlash 6/10 energy dispersive X-ray detector.

\subsection{Elemental geochemical analysis}

The carbonate sidewall samples were powdered in an agate pestle for all the geochemical analysis. Major and trace elements concentrations were determined using a Philips PW2400 X-ray spectrometer at the Geochemistry Laboratory of the Petrology and Metallogeny Department of the São Paulo State University. For major elements analysis, $\sim 0.7 \mathrm{~g}$ of carbonate powder was melted with $6.5 \mathrm{~g}$ of $\mathrm{Li}_{2} \mathrm{~B}_{4} \mathrm{O}_{7}$. $\mathrm{Rb}$ and $\mathrm{Sr}$ analysis was undertaken using $\mathrm{x}$-ray fluorescence of $6.0 \mathrm{~g}$ of carbonate powders mixed with $1.5 \mathrm{~g}$ of wax binder. This mixture was covered with $\mathrm{H}_{3} \mathrm{BO}_{3}$ and then pressed. Only 13 of the total sidewall samples had sufficient weight for the $\mathrm{Rb}$ and $\mathrm{Sr}$ measurements by $\mathrm{x}$-ray fluorescence technique.

\subsection{TOC and pyrolysis}

Approximately $250.0 \pm 0.2 \mathrm{mg}$ of limestone powder was leached with $\mathrm{HCl} 50 \%$ for $12 \mathrm{~h}$. Insoluble residues were first washed with distilled water at $100{ }^{\circ} \mathrm{C}$ and then five more times at ambient temperature to eliminate chlorides. After drying, the residues were weighed to determine the insoluble residue. TOC contents were measured using a LECO SC632 Sulfur/Carbon determinator. Samples with TOC contents higher than $0.50 \%$ were selected for pyrolysis, performed in a Vinci Rock-Eval 6 by burning $70 \mathrm{mg}$ of whole-rock limestone powders. Hydrogen Index (HI) was calculated by $\mathrm{HI}=(\mathrm{S} 2 / \mathrm{TOC}) \times 100$, expressed in $\mathrm{mgHC} / \mathrm{gTOC}$. TOC and pyrolysis 

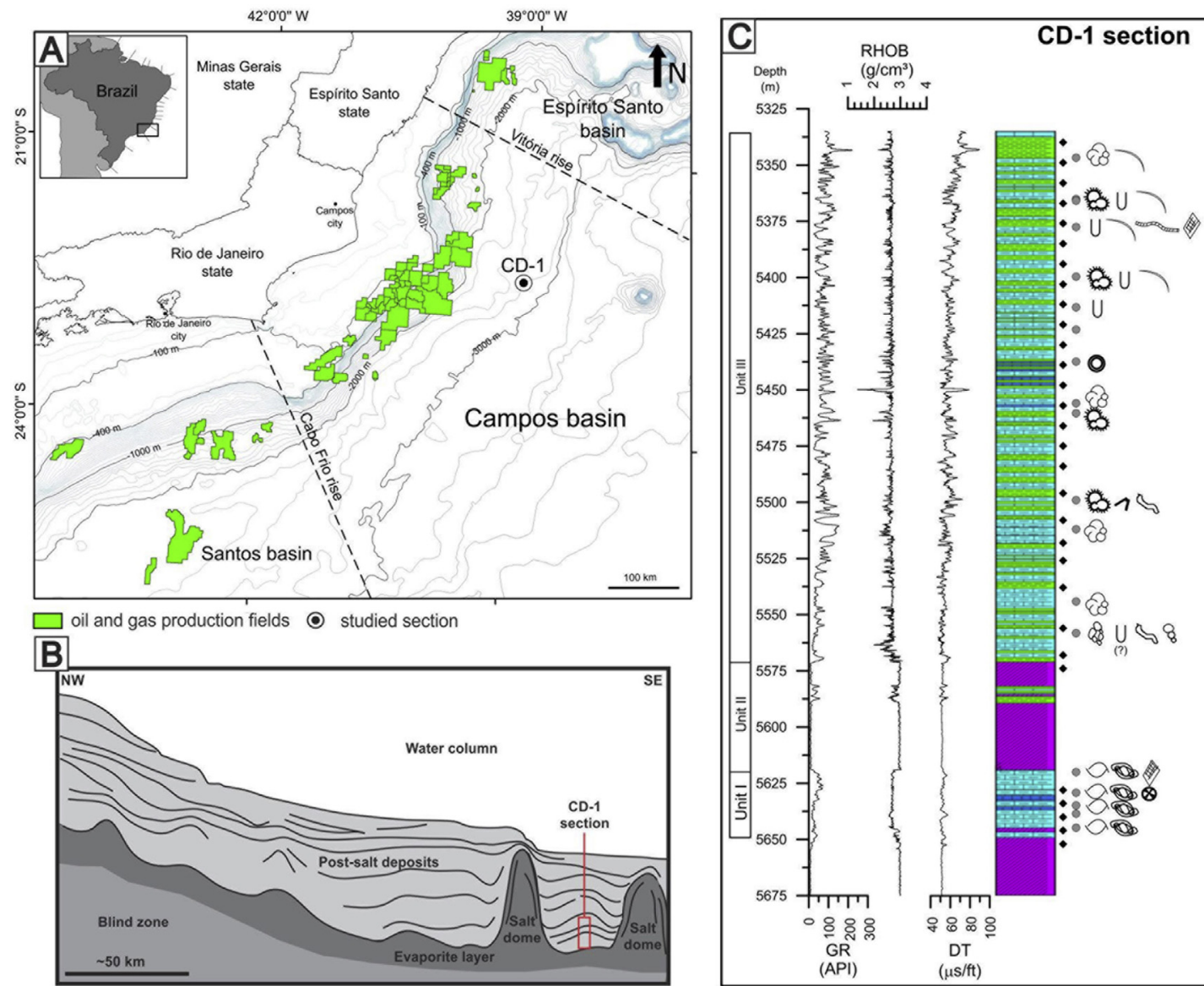

\begin{tabular}{|c|c|}
\hline & iples \\
\hline - & sidewall samples \\
\hline & cuttings \\
\hline & lasts \\
\hline$\otimes$ & green algae cysts \\
\hline . & miliolids \\
\hline a & ostracodes \\
\hline 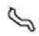 & bioturbation \\
\hline 88 & agglutinated foraminifers \\
\hline & equinoid fragments \\
\hline & pelagic calcispheres \\
\hline & pelagic crinoids \\
\hline & inoceramids \\
\hline & Microcalamoides diversus \\
\hline U & Colomiella recta \\
\hline 8 & hedbergelliform foraminifers \\
\hline to & Favusella washitensis \\
\hline te & hyaline benthic foraminifers \\
\hline & ology \\
\hline & shale \\
\hline & calcarenite \\
\hline & calcilutite \\
\hline & anhydrite \\
\hline
\end{tabular}

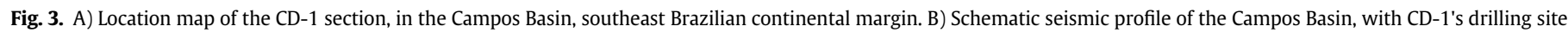

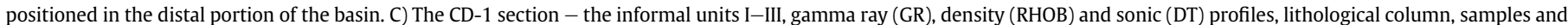
microfossil content along the studied interval.

analyses were carried out in the Chemical Stratigraphy and Organic Geochemistry Laboratory at the Rio de Janeiro State University.

\section{4. $C$ and $O$ stable isotopes}

Carbon and oxygen stable isotopes analysis in carbonates were carried out in 18 sidewall and 30 cutting samples. Stable isotope data are reported in $\delta$ notation, relative to the VPDB standard.

Sidewall samples were analysed at the Chemical Stratigraphy and Organic Geochemistry laboratory at the Rio de Janeiro State University. Carbonate powders were acidified with $\mathrm{H}_{3} \mathrm{PO}_{4} 100 \%$ in a Kiel IV Carbonate Device, under a He atmosphere. Carbon and oxygen stable isotope compositions from the $\mathrm{CO}_{2}$ extracted were determined in a ThermoFischer Delta V Plus mass spectrometer. The standard IAEACO1 was run every ten samples. Average standard deviations of carbon and oxygen isotope analysis in sidewall samples were 0.024 and $0.020 \%$, respectively.

Limestone fragments were picked out from the cuttings and then were powdered in an agate pestle. About $10 \mathrm{mg}$ of carbonate powder was acidified with $100 \% \mathrm{H}_{3} \mathrm{PO}_{4}$, at $25{ }^{\circ} \mathrm{C}$ for $24 \mathrm{~h}$. $\mathrm{C}$ and $\mathrm{O}$ isotope compositions of the released $\mathrm{CO}_{2}$ were measured using a Thermo Delta V Advantage mass spectrometer, at the Stable Isotope laboratory of the Center of Geochronological Research (CPGeo), University of São Paulo. The standards NBS-18 and NBS-19 were run before and after the 30 samples. Average standard deviations of carbon and oxygen isotopes analysis in cuttings samples were 0.1 and $0.2 \%$, respectively.

\section{5. ${ }^{87} \mathrm{Sr} /{ }^{86} \mathrm{Sr}$ ratios}

$\mathrm{Sr}$ isotope compositions were obtained from whole-rock through a two-step leaching process. First, approximately 70-100 mg of carbonate powder were leached with $0.1 \mathrm{~N} \mathrm{HCl}$ for an hour. After drying, the samples were centrifuged and washed three times with deionized Milli Q water. The first leachate was discarded. The residues were then reacted with $1 \mathrm{~N} \mathrm{HCl}$ for $30 \mathrm{~min}$, in order to leach ca. $70 \%$ of the sample mass. After drying, samples were centrifuged and washed three times. The second leachates were purified by an ion exchange chromatography technique with $\mathrm{Sr}$ spec resin. Their ${ }^{87} \mathrm{Sr} /{ }^{86} \mathrm{Sr}$ ratios were determined on a thermal ionization mass spectrometer ThermoFischer Triton at the Center of Geochronological Research (CPGeo), University of São Paulo. The ${ }^{87} \mathrm{Sr} /{ }^{86} \mathrm{Sr}$ ratios were normalized for the value 0.1194 . The average value of the NBS-987 standard measures was $0.710243 \pm 0.000025$.

Due to low $\mathrm{Sr}$ concentrations and high $\mathrm{Rb} / \mathrm{Sr}$ ratios of the samples, the ${ }^{87} \mathrm{Sr} /{ }^{86} \mathrm{Sr}$ ratios were corrected for the contribution of radiogenic ${ }^{87} \mathrm{Sr}$ derived from ${ }^{87} \mathrm{Rb}$ decay in Rb-rich minerals (siliciclastic terrigenous components), which may have been exchanged with the carbonates during diagenesis. This correction is derived from the law of radioactivity, for the $\mathrm{Rb}-\mathrm{Sr}$ method (Faure and Mensing, 2005):

$$
{ }^{87} \mathrm{Sr} /{ }^{86} \mathrm{Sr}_{\text {initial }}={ }^{87} \mathrm{Sr} /{ }^{86} \mathrm{Sr}_{\text {measured }}-{ }^{87} \mathrm{Rb} /{ }^{86} \mathrm{Sr}[\exp (\lambda \mathrm{t})-1]
$$


where the decay constant ${ }^{87} \mathrm{Rb}(\lambda)$ equals $1.42 \times 10^{-11} \mathrm{y}^{-1}$ and the estimated average age for the deposition of studied rocks $(t)$ is $115 \times 10^{6} \mathrm{y}$. Each term of this equation was divided by the nonradiogenic ${ }^{86} \mathrm{Sr}$ isotope, under the assumption that it remains constant through time (Faure and Mensing, 2005). ${ }^{87} \mathrm{Sr} /{ }^{86} \mathrm{Sr}_{\text {initial }}$ is the corrected ratio whereas ${ }^{87} \mathrm{Sr} /{ }^{86} \mathrm{Sr}_{\text {measured }}$ is the original one. The ${ }^{87} \mathrm{Rb} /{ }^{86} \mathrm{Sr}$ isotopic ratios were calculated from the measured $\mathrm{Rb} / \mathrm{Sr}$ concentration ratios, following the relation:

${ }^{87} \mathrm{Rb} /{ }^{86} \mathrm{Sr}=[\mathrm{Rb}] /[\mathrm{Sr}] \times 2.89$ (Faure and Mensing, 2005)

\section{Results}

\subsection{Microfacies analysis of carbonate rocks}

Five microfacies associations (MA) were identified in units I and III. Unit I contained microfacies associations dominated by benthic organisms (MA-1 and MA-2; Fig. 4 and 5, respectively) related to shallower and more oxygenated conditions. In unit III, benthic organisms are absent or very rare (MA-3; Fig. 6) and planktic organisms predominate (MA-4, and MA-5; Fig. 7 and 8, respectively), which is related to deeper and oxygen-depleted bottom water conditions. These pelagic limestones are dark-coloured (dark blue to dark grey) and contain relatively high TOC contents (section 4.5) and abundant framboidal pyrite. Regarding diagenetic processes, the microfacies from unit III show more preserved depositional textures, such as well-preserved micrite matrix, while unit I displayed more intense diagenetic features, as recrystallization and dolomitisation.

MA-1 is composed of benthic-dominated bioclastic wackestones, in which miliolids and ostracodes predominate (Fig. 4). Echinoderms fragments, green algae, and hyaline benthic foraminifera are less frequent in this microfacies association. The matrix consists of micrite and the detrital silt content is low. The two lowest sidewall samples at depths of 5644.8 and $5638.5 \mathrm{~m}$ have relatively high calcium contents (Table 1; section 4.3) and displayed evidence of intense mineral recrystallization, as microspar calcite and saddle dolomites, which were attributed to burial diagenesis. Dolomite crystals contain porphyritic textures and dull luminescence under CL (Fig. 4), indicating the presence of Fe which was also confirmed by SEM/EDS analysis.

MA-2 encompasses bioclastic/peloid packstones and bioclastic/ oolitic wackestones, with incipient detrital silt/clay lamination (Fig. 5). Bioclasts are dominated by benthic biota, especially miliolids and ostracodes, similar to MA-1. Ooids retrieved in wackestone microfacies were interpreted as allochthonous, transported from an oolitic shoal.

MA-3 is characterized by bioclastic wackestones and micropeloid/bioclastic packstones, with associated bioturbation (Fig. 6). Bioclasts correspond to agglutinated foraminifera, pelagic microcrinoids (roveacrinids), and planktic foraminifera (hedbergelliform elements). Bioturbation was interpreted as worm tubes.

MA-4 comprises planktic-dominated bioclastic wackestones and mudstones, with notable occurrences of the planktic foraminifera Favusella washitensis (Carsey 1926), the colomiellid Colomiella recta Bonet 1956, and the pelagic microcrinoid Microcalamoides diversus Bonet 1956 (Fig. 7). The matrix is composed of micrite and nannofossils (Nannoconus spp.), with low contents of detrital silt. The abundance of framboidal pyrite pointed to sulphate-reduction activity in an oxygen-depleted penecontemporaneous to eodiagenetic environment. This microfacies association intercalates with black shales in high frequency cycles, interpreted from the gamma ray log and cuttings analysis.
MA-5 is characterized by abundance of detrital silt content (5-10\%), as angular grains, and similar abundance of planktondominated bioclasts. Hence, this microfacies association is composed of planktic-dominated bioclastic wackestones, in which F. washitensis, C. recta and M. diversus predominate (Fig. 8). The cooccurrence of glauconite grains, Fe-Mn oxides (Fig. 9), and framboidal pyrite (Fig. 8) suggests sediment reworking from shallower waters, under more oxygenated bottom conditions, and its transport to deeper portions of the ramp, under oxygen depleted bottom environments. In combination with the abundance of detrital silt and bioclasts, this microfacies association was interpreted as allochthonous deposits (tempestites).

The co-occurrence of $F$. washitensis, $C$. recta and $M$. diversus represents a typical Tethyan opportunistic pelagic biota within the proto-oceanic South Atlantic (Dias-Brito and Ferré, 2001). This association was reported in studies from the Gulf of Mexico, Mexico, the Western Carpathians, the Caribbean sea, the eastern Brazilian and western African margins (e.g. Chevalier and Fischer, 1982; Premoli-Silva and McNulty, 1984; Dias-Brito and Ferré, 2001; González-León et al., 2008; Michalík et al., 2012). Microfacies studies have positioned this association in the late Aptian-early Albian interval (e.g., Longoria and Monreal, 2009; Núñez-Useche and Barragán, 2012).

\subsection{Carbon and oxygen stable isotopes}

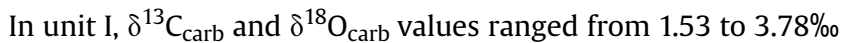
and from -7.20 to $-1.13 \%$, respectively (Table 1 ). With the exception of the two basal cuttings samples, the $\delta^{13} \mathrm{C}_{\text {carb }}$ profile shows decreasing values towards the top of this unit, while $\delta^{18} \mathrm{O}_{\text {carb }}$ profile covary inversely (Fig. 10). Unit III has $\delta^{13} \mathrm{C}_{\text {carb }}$ and $\delta^{18} \mathrm{O}_{\text {carb }}$ values ranging from -0.23 to $3.09 \%$ and -6.63 to $-1.38 \%$, respectively (Table 1 ). The $\delta^{13} \mathrm{C}_{\text {carb }}$ and $\delta^{18} \mathrm{O}_{\text {carb }}$ profiles display an independent behaviour, with $\delta^{13} \mathrm{C}_{\text {carb }}$ curve fluctuating mostly between 1 and $3 \%$ along the unit, whereas $\delta^{18} \mathrm{O}_{\text {carb }}$ profile consists of a negative excursion (Fig. 10).

\subsection{Major, minor, and trace elements}

The lithophile elements $\mathrm{Si}, \mathrm{Al}$, and $\mathrm{K}$ contents ranged from 0.43 to $6.48 \%, 0.08$ to $3.27 \%$, and 0.02 to $1.15 \%$ (Table 1 ), respectively, and are directly associated with the siliciclastic terrigenous contents of the limestones. In fact, MA-5 presented the highest percentages of these elements (Fig. 10), which is associated with the increased terrigenous content of this microfacies association (Figs. 8 and 9).

$\mathrm{Ca}$ is the primary cation present, with concentrations varying from 31.13 to $51.76 \%$ and reflecting the calcium carbonate nature of these rocks (Table 1; Fig. 10). The highest values are associated with the two most basal sidewall samples of unit I, which are intensely recrystallized due to their higher calcium carbonate content. Mg contents range from 0.34 to $1.25 \%$ and are associated with the carbonates (Mg-calcite, mainly, and dolomite), with the exception of the highest values of $1.14 \%$ and $1.25 \%$ (depths 5620.0 and 5634.9 m, respectively; Fig. 10) which are related to high terrigenous contribution.

Fe contents range from 0.23 to $3.27 \%$ and are directly correlated to the lithophiles (terrigenous phases) in unit I and at the top of unit III, whereas in most of the unit III, its behaviour is decoupled from other elements (Fig. 10). In this case, Fe is present in pyrites and dolomites, which are associated with early and late burial diagenesis, respectively. Mn concentrations range from 0.04 to $0.41 \%$, with the highest values $(0.33-0.41 \%)$ presented in the top of unit III (MA5 ), also in direct correlation with the lithophiles (Fig. 10). In the rest of section, Mn varies from 0.04 to $0.08 \%$ and is primarily associated to the carbonates. MA-5 displays Fe-Mn oxides, marking a change 


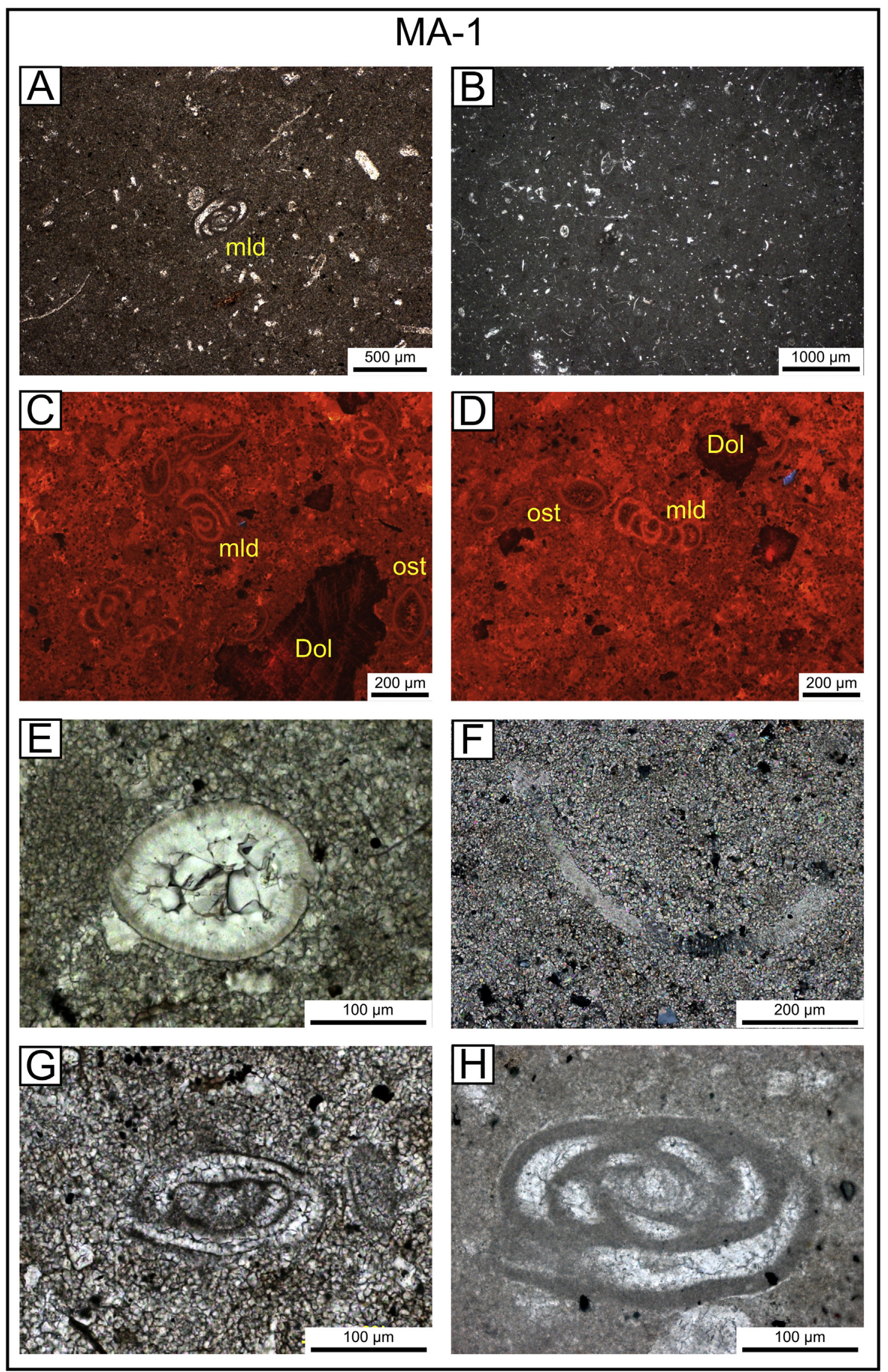

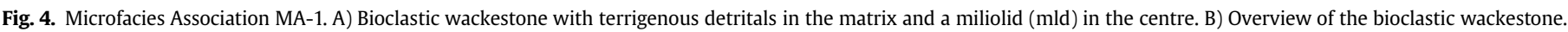

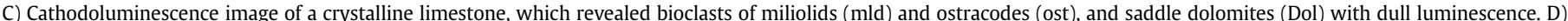

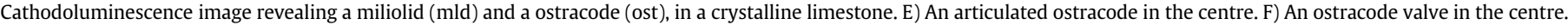
G) A miliolid in the centre. H) Another miliolid in the centre. 


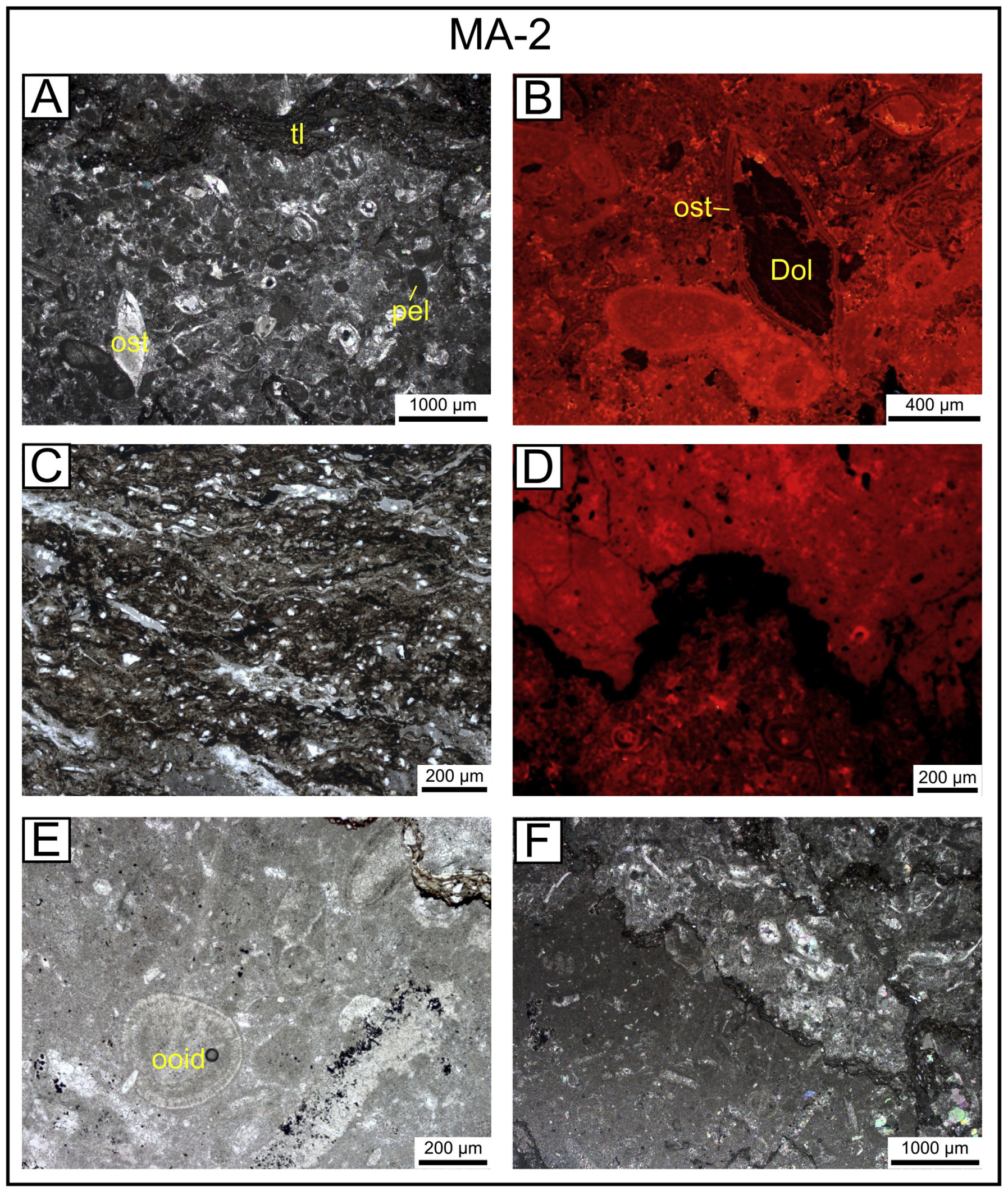

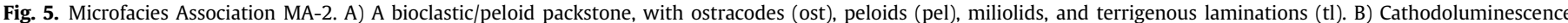

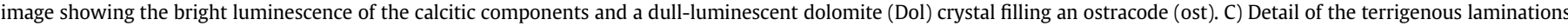

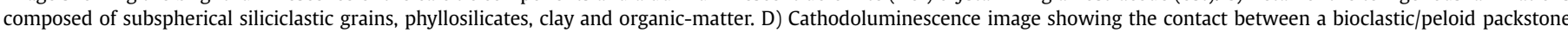

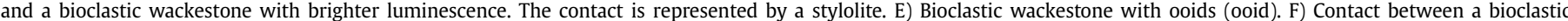
wackestone (on the base) and a bioclastic/peloid packstone (on the top). 


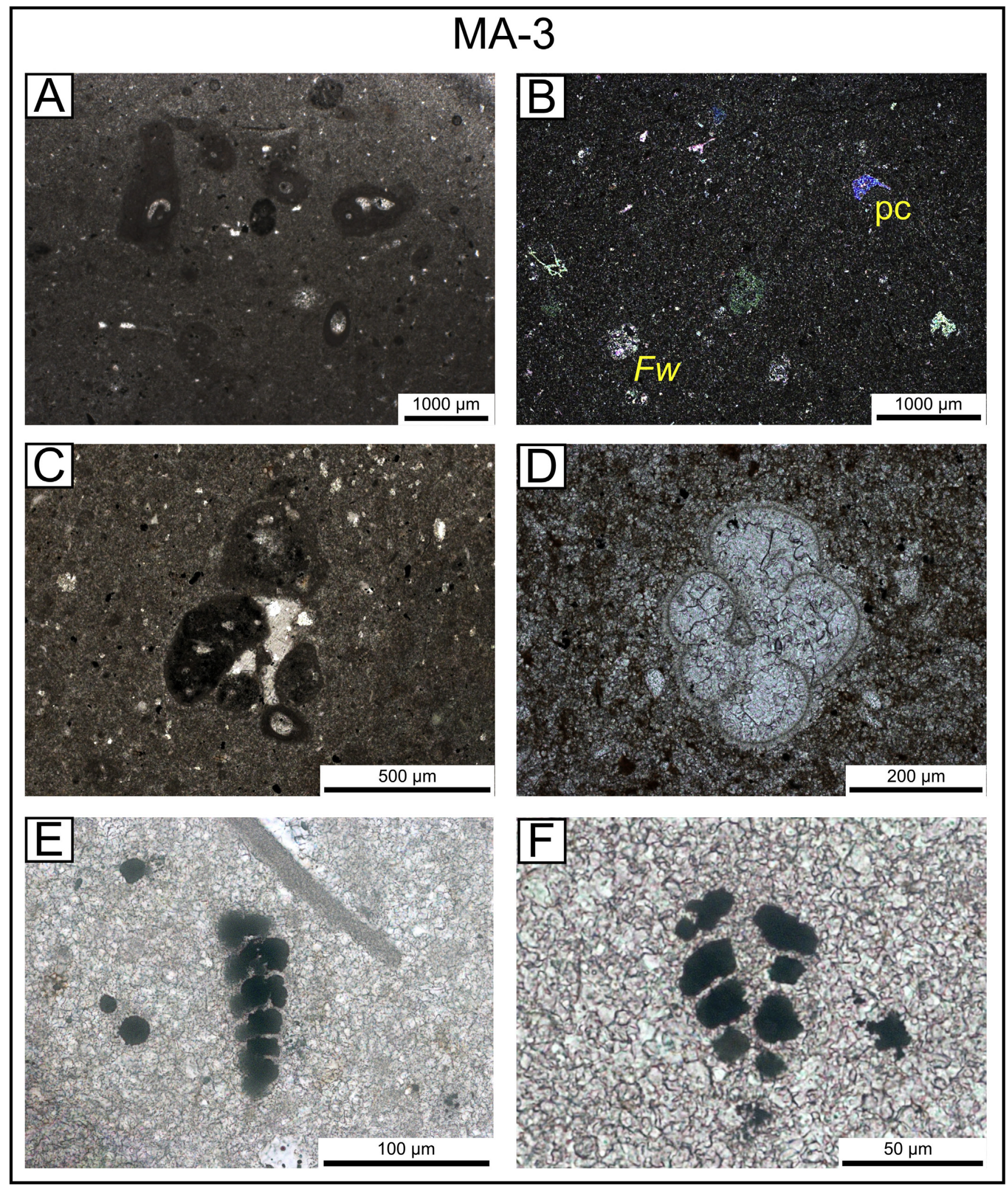

Fig. 6. Microfacies Association MA-3. A) Bioclastic wackestone with bioturbations (worm tubes). B) Bioclastic wackestone with pelagic crinoids (pc) and the planktic foraminifer Favusella washitensis $(F w)$. C) An agglutinated foraminifer in detail in a bioclastic wackestone. D) Favusella washitensis in detail. E) Bioclastic wackestone with a benthic foraminifer filled by pyrite in detail, in a recrystallized matrix containing pyrite framboids, F) Another benthic foraminifer filled by pyrite in detail within the recrystallized matrix. 


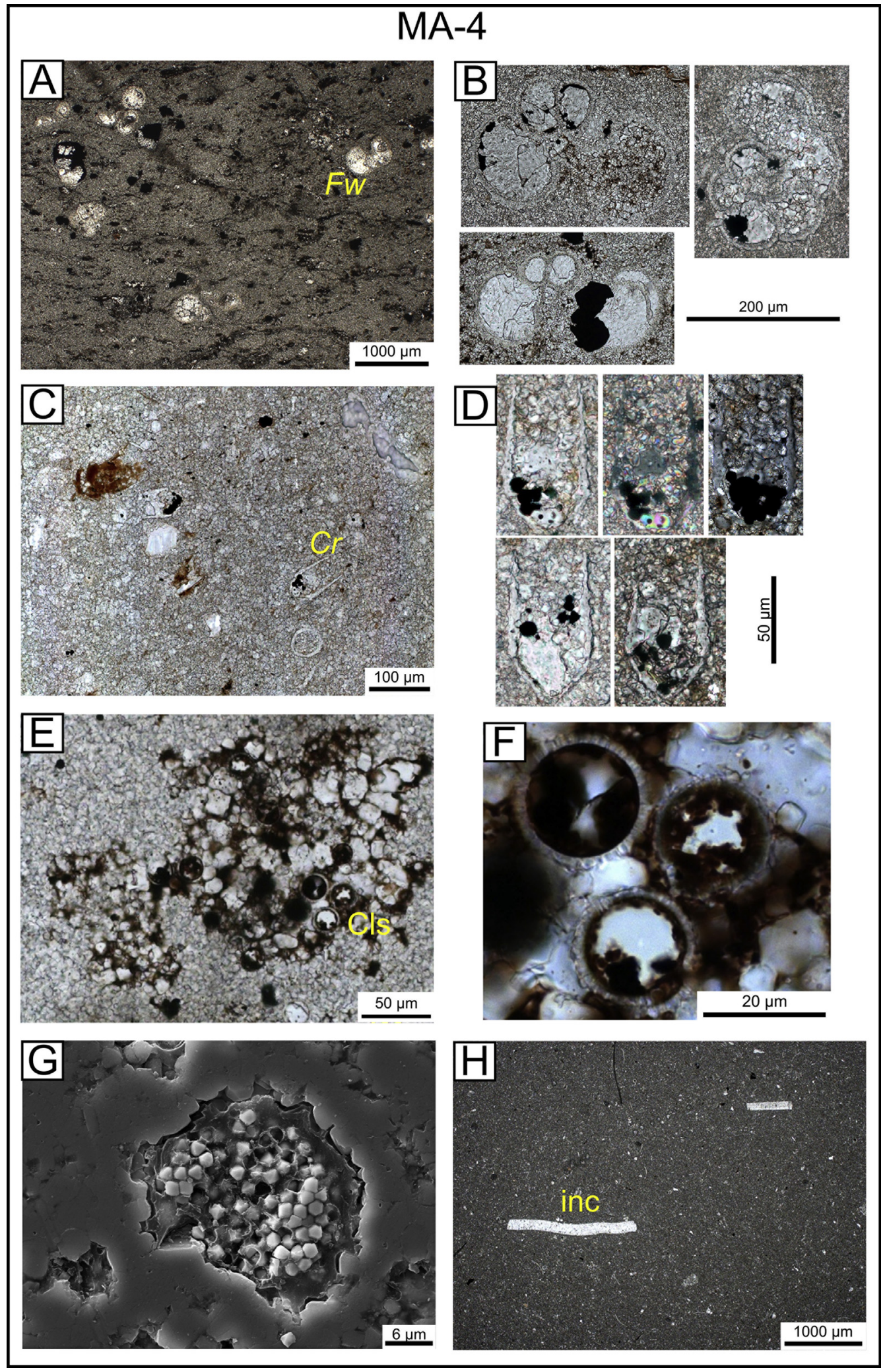

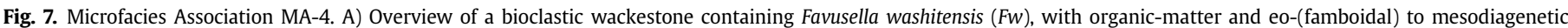

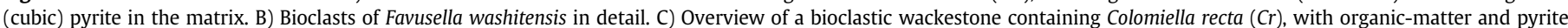

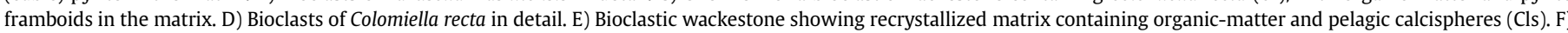

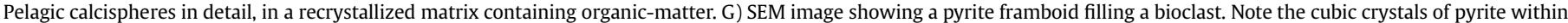
organic-matter. H) Overview of a mudstone containing inoceramids fragments. 


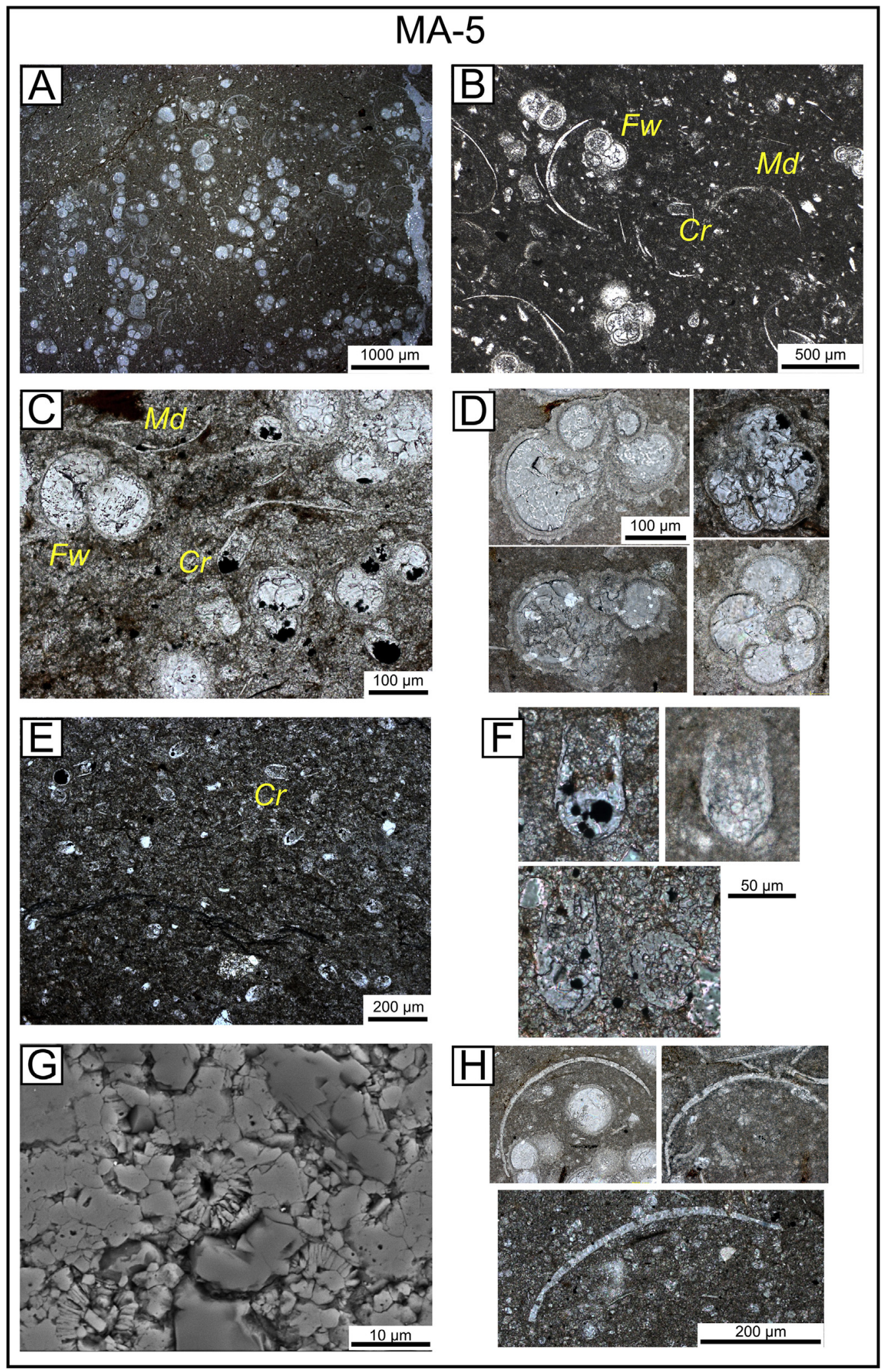

Fig. 8. Microfacies Association MA-5. A) Overview of a bioclastic wackestone with abundance of bioclasts and terrigenous grains, interpreted as tempestites. B) The association of Favusella washitensis ( Fw), Colomiella recta (Cr), and Microcalamoides diversus (Md) in detail, in a bioclastic wackestone. C) Another image of the association of Favusella washitensis $(\mathrm{Fw})$, Colomiella recta $(\mathrm{Cr})$, and Microcalamoides diversus $(\mathrm{Md})$, containing pyrite framboids and organic-matter in the matrix. D) Favusella washitensis in detail. E) Overview of a bioclastic wackestone with abundant Colomiella recta ( $\mathrm{Cr}$ ) bioclasts and terrigenous grains. F) Bioclasts of Colomiella recta in detail. G) SEM image showing the matrix of the bioclastic wackestones of the MA-5, containing micrite (lighter colour), terrigenous components (darker colour), and Nannoconus spp. in the centre. H) Microcalamoides diversus in detail. 
Table 1

$\mathrm{C}$ and $\mathrm{O}$ stable isotopes, major, and trace ( $\mathrm{Rb}$ and $\mathrm{Sr}$ ) elements from the limestones of the $\mathrm{CD}-1$ section.

\begin{tabular}{|c|c|c|c|c|c|c|c|c|c|c|c|c|c|c|}
\hline & Depth (m) & $\begin{array}{l}\text { Sample } \\
\text { type }\end{array}$ & $\begin{array}{l}\text { Microfacies } \\
\text { association }\end{array}$ & $\begin{array}{l}\delta^{13} C_{\text {carb }} \\
(\% \circ \mathrm{V}-\mathrm{PDB})\end{array}$ & $\begin{array}{l}\delta^{18} \mathrm{O}_{\text {carb }} \\
(\% \circ \mathrm{V}-\mathrm{PDB})\end{array}$ & Si (\%) & $\mathrm{Al}(\%)$ & $\mathrm{Fe}(\%)$ & Mn (\%) & $\mathrm{Mg}(\%)$ & $\mathrm{Ca}(\%)$ & $\mathrm{K}(\%)$ & $\mathrm{Rb}(\mathrm{ppm})$ & $\mathrm{Sr}(\mathrm{ppm})$ \\
\hline \multirow[t]{38}{*}{ Unit III } & 5340.0 & Cuttings & n.a. & 2.3 & -6.0 & n.a. & n.a. & n.a. & n.a. & n.a. & n.a. & n.a. & n.a. & n.a. \\
\hline & 5346.8 & Sidewall & MA-5 & -0.23 & -4.59 & 5.72 & 1.58 & 1.18 & 0.38 & 0.72 & 33.18 & 0.84 & 27 & 339 \\
\hline & 5349.0 & Cuttings & n.a. & 2.4 & -5.7 & n.a. & n.a. & n.a. & n.a. & n.a. & n.a. & n.a. & n.a. & n.a. \\
\hline & 5358.0 & Cuttings & n.a. & 2.0 & -5.8 & n.a. & n.a. & n.a. & n.a. & n.a. & n.a. & n.a. & n.a. & n.a. \\
\hline & 5365.1 & Sidewall & MA-5 & 0.05 & -3.49 & 4.51 & 1.25 & 0.64 & 0.41 & 0.47 & 34.71 & 0.68 & 21 & 349 \\
\hline & 5365.8 & Sidewall & MA-5 & 0.25 & -5.10 & 4.92 & 1.57 & 0.90 & 0.33 & 0.56 & 33.43 & 0.86 & 25 & 378 \\
\hline & 5367.0 & Cuttings & n.a. & 1.8 & -6.0 & n.a. & n.a. & n.a. & n.a. & n.a. & n.a. & n.a. & n.a. & n.a. \\
\hline & 5376.0 & Cuttings & n.a. & 1.9 & -6.5 & n.a. & n.a. & n.a. & n.a. & n.a. & n.a. & n.a. & n.a. & n.a. \\
\hline & 5377.5 & Sidewall & MA-4 & 2.16 & -4.73 & 1.08 & 0.32 & 0.28 & 0.08 & 0.34 & 39.96 & 0.14 & 10 & 230 \\
\hline & 5385.0 & Cuttings & n.a. & 2.0 & -6.6 & n.a. & n.a. & n.a. & n.a. & n.a. & n.a. & n.a. & n.a. & n.a. \\
\hline & 5394.0 & Cuttings & n.a. & 1.8 & -6.5 & n.a. & n.a. & n.a. & n.a. & n.a. & n.a. & n.a. & n.a. & n.a. \\
\hline & 5399.6 & Sidewall & MA-5 & 1.82 & -5.33 & 3.22 & 0.97 & 0.59 & 0.07 & 0.45 & 36.73 & 0.47 & n.a. & n.a. \\
\hline & 5403.0 & Cuttings & n.a. & 1.4 & -5.8 & n.a. & n.a. & n.a. & n.a. & n.a. & n.a. & n.a. & n.a. & n.a. \\
\hline & 5412.0 & Cuttings & n.a. & 2.4 & -5.4 & n.a. & n.a. & n.a. & n.a. & n.a. & n.a. & n.a. & n.a. & n.a. \\
\hline & 5413.5 & Sidewall & MA-5 & 1.87 & -4.18 & 6.48 & 2.05 & 1.10 & 0.05 & 0.59 & 31.13 & 1.05 & 26 & 259 \\
\hline & 5421.0 & Cuttings & n.a. & 2.2 & -4.6 & n.a. & n.a. & n.a. & n.a. & n.a. & n.a. & n.a. & n.a. & n.a. \\
\hline & 5423.2 & Sidewall & MA-4 & 1.97 & -2.49 & 0.82 & 0.25 & 0.23 & 0.04 & 0.46 & 39.10 & 0.08 & n.a. & n.a. \\
\hline & 5430.0 & Cuttings & n.a. & 1.1 & -6.6 & n.a. & n.a. & n.a. & n.a. & n.a. & n.a. & n.a. & n.a. & n.a. \\
\hline & 5439.0 & Cuttings & n.a. & 1.0 & -4.1 & n.a. & n.a. & n.a. & n.a. & n.a. & n.a. & n.a. & n.a. & n.a. \\
\hline & 5448.0 & Cuttings & n.a. & 1.2 & -4.7 & n.a. & n.a. & n.a. & n.a. & n.a. & n.a. & n.a. & n.a. & n.a. \\
\hline & 5456.0 & Sidewall & MA-4 & 2.54 & -3.56 & 2.77 & 0.83 & 0.65 & 0.06 & 0.47 & 36.50 & 0.40 & n.a. & n.a. \\
\hline & 5457.0 & Cuttings & n.a. & 1.0 & -4.6 & n.a. & n.a. & n.a. & n.a. & n.a. & n.a. & n.a. & n.a. & n.a. \\
\hline & 5460.4 & Sidewall & MA-4 & 2.32 & -2.66 & 1.79 & 0.67 & 3.27 & 0.08 & 0.46 & 38.23 & 0.29 & n.a. & n.a. \\
\hline & 5466.0 & Cuttings & n.a. & 1.4 & -4.9 & n.a. & n.a. & n.a. & n.a. & n.a. & n.a. & n.a. & n.a. & n.a. \\
\hline & 5475.0 & Cuttings & n.a. & 1.3 & -4.0 & n.a. & n.a. & n.a. & n.a. & n.a. & n.a. & n.a. & n.a. & n.a. \\
\hline & 5484.0 & Cuttings & n.a. & 2.4 & -1.4 & n.a. & n.a. & n.a. & n.a. & n.a. & n.a. & n.a. & n.a. & n.a. \\
\hline & 5496.0 & Cuttings & n.a. & 1.7 & -3.2 & n.a. & n.a. & n.a. & n.a. & n.a. & n.a. & n.a. & n.a. & n.a. \\
\hline & 5499.1 & Sidewall & MA-3 & 1.07 & -3.03 & 2.93 & 0.89 & 0.51 & 0.04 & 0.59 & 35.87 & 0.41 & 15 & 343 \\
\hline & 5508.0 & Cuttings & n.a. & 2.6 & -4.1 & n.a. & n.a. & n.a. & n.a. & n.a. & n.a. & n.a. & n.a. & n.a. \\
\hline & 5512.0 & Sidewall & MA-4 & 0.70 & -2.33 & 1.17 & 0.27 & 0.29 & 0.04 & 0.60 & 38.31 & 0.11 & 10 & 255 \\
\hline & 5518.0 & Cuttings & n.a. & 1.5 & -3.5 & n.a. & n.a. & n.a. & n.a. & n.a. & n.a. & n.a. & n.a. & n.a. \\
\hline & 5526.0 & Cuttings & n.a. & 1.9 & -3.3 & n.a. & n.a. & n.a. & n.a. & n.a. & n.a. & n.a. & n.a. & n.a. \\
\hline & 5538.0 & Cuttings & n.a. & 1.9 & -2.7 & n.a. & n.a. & n.a. & n.a. & n.a. & n.a. & n.a. & n.a. & n.a. \\
\hline & 5544.2 & Sidewall & MA-4 & 3.09 & -3.70 & 1.54 & 0.43 & 0.41 & 0.07 & 0.44 & 38.67 & 0.20 & n.a. & n.a. \\
\hline & 5556.0 & Cuttings & n.a. & 1.9 & -2.7 & n.a. & n.a. & n.a. & n.a. & n.a. & n.a. & n.a. & n.a. & n.a. \\
\hline & 5558.3 & Sidewall & MA-3 & 2.08 & -2.85 & 4.00 & 1.38 & 0.88 & 0.07 & 0.72 & 32.48 & 0.78 & 20 & 234 \\
\hline & 5568.0 & Cuttings & n.a. & 0.6 & -4.2 & n.a. & n.a. & n.a. & n.a. & n.a. & n.a. & n.a. & n.a. & n.a. \\
\hline & 5574.0 & Cuttings & n.a. & 1.6 & -1.9 & n.a. & n.a. & n.a. & n.a. & n.a. & n.a. & n.a. & n.a. & n.a. \\
\hline \multirow[t]{10}{*}{ Unit I } & 5620.0 & Sidewall & MA-1 & 2.73 & -1.13 & 2.55 & 0.68 & 0.51 & 0.05 & 1.14 & 38.29 & 0.43 & 15 & 401 \\
\hline & 5628.0 & Cuttings & n.a. & 2.3 & -3.5 & n.a. & n.a. & n.a. & n.a. & n.a. & n.a. & n.a. & n.a. & n.a. \\
\hline & 5629.3 & Sidewall & MA-1 & 2.87 & -3.56 & 1.32 & 0.31 & 0.31 & 0.06 & 0.50 & 42.22 & 0.18 & 11 & 275 \\
\hline & 5634.0 & Cuttings & n.a. & 1.9 & -3.1 & n.a. & n.a. & n.a. & n.a. & n.a. & n.a. & n.a. & n.a. & n.a. \\
\hline & 5634.9 & Sidewall & MA-2 & 3.04 & -4.18 & 5.90 & 1.81 & 1.80 & 0.06 & 1.25 & 32.89 & 1.15 & 24 & 235 \\
\hline & 5638.5 & Sidewall & MA-2 & 3.72 & -7.20 & 0.43 & 0.08 & 0.23 & 0.07 & 1.16 & 49.54 & 0.02 & 8 & 196 \\
\hline & 5640.0 & Cuttings & n.a. & 3.1 & -4.3 & n.a. & n.a. & n.a. & n.a. & n.a. & n.a. & n.a. & n.a. & n.a. \\
\hline & 5644.8 & Sidewall & MA-1 & 3.78 & -5.80 & 1.39 & 0.40 & 0.49 & 0.07 & 0.82 & 51.76 & 0.26 & 11 & 228 \\
\hline & 5646.0 & Cuttings & n.a. & 1.5 & -2.9 & n.a. & n.a. & n.a. & n.a. & n.a. & n.a. & n.a. & n.a. & n.a. \\
\hline & 5652.0 & Cuttings & n.a. & 2.3 & -2.4 & n.a. & n.a. & n.a. & n.a. & n.a. & n.a. & n.a. & n.a. & n.a. \\
\hline
\end{tabular}

Notes: (n.a.) not analysed.

in Mn-bearing minerals in the top of unit III, formed under oxic conditions (Fig. 9).

Carbonate rocks of $\mathrm{CD}-1$ section yield $\mathrm{Rb}$ and $\mathrm{Sr}$ contents between 8 to $27 \mathrm{ppm}$ and 196 to $401 \mathrm{ppm}$, respectively (Table 1 ). $\mathrm{Rb}$ correlates with the lithophiles, whereas $\mathrm{Sr}$ is associated with $\mathrm{Ca}$ in the carbonates (Fig. 10). Sr contents are low for carbonate rocks ( 500 ppm; Reimann and Caritat, 1998), with average and median of 286 and 259 ppm, respectively.

\section{4. ${ }^{87} \mathrm{Sr} /{ }^{86} \mathrm{Sr}$ ratios}

${ }^{87} \mathrm{Sr} /{ }^{86} \mathrm{Sr}$ and $\mathrm{Rb} / \mathrm{Sr}$ ratios are shown in Table 2, as well as the corrected ${ }^{87} \mathrm{Sr} /{ }^{86} \mathrm{Sr}$ ratios for radiogenic ${ }^{87} \mathrm{Sr}$ contribution $\left.{ }^{87} \mathrm{Sr} /{ }^{86} \mathrm{Sr}_{\text {initial }}\right)$. Carbonates of $\mathrm{CD}-1$ section yielded ${ }^{87} \mathrm{Sr} /{ }^{86} \mathrm{Sr}$ ratios ranging from 0.7074 to 0.7077 . They are more radiogenic towards the top of the section, following an increase in terrigenous input as recorded in the microfacies and by the lithophiles profiles (Fig. 10). As presented earlier, due to the low $\mathrm{Sr}$ contents of these rocks, and consequently high $\mathrm{Rb} / \mathrm{Sr}$ ratios (0.039-0.100; Table 2), the measured ${ }^{87} \mathrm{Sr} /{ }^{86} \mathrm{Sr}$ ratios were corrected by the $\mathrm{Rb}-\mathrm{Sr}$ radiogenic decay equation $\left({ }^{87} \mathrm{Sr} /{ }^{86} \mathrm{Sr}_{\text {initial}}\right.$; section 3.5$)$. The calculated ${ }^{87} \mathrm{Sr} /{ }^{86} \mathrm{Sr}_{\text {initial }}$ ratios varied from 0.7072 to 0.7074 , on average 0.0003 less radiogenic than the ${ }^{87} \mathrm{Sr} /{ }^{86} \mathrm{Sr}_{\text {measured }}$ ratios (Table 2), and are in accordance with the late Aptian-early Albian interval of the reference ${ }^{87} \mathrm{Sr} /{ }^{86} \mathrm{Sr}$ curves (e.g. Bralower et al., 1997; Bodin et al., 2015).

\subsection{TOC and pyrolysis}

TOC, insoluble residues, $\mathrm{S} 2, \mathrm{~T}_{\max }$ and $\mathrm{HI}$ from limestones of the CD-1 section are given in Table 3 . TOC contents ranged between 0.09 and $1.94 \%$ and from 0.17 to $2.49 \%$ for units I and III, respectively. Despite a sample at $5634.9 \mathrm{~m}$ depth, which has increased TOC of $1.94 \%$, TOC contents are low in unit I (MA-1 and 2), with average and median of 0.51 and 0.21 , respectively (Table 3 ). In turn, unit III displayed substantial TOC amounts throughout the section (MA-3, 

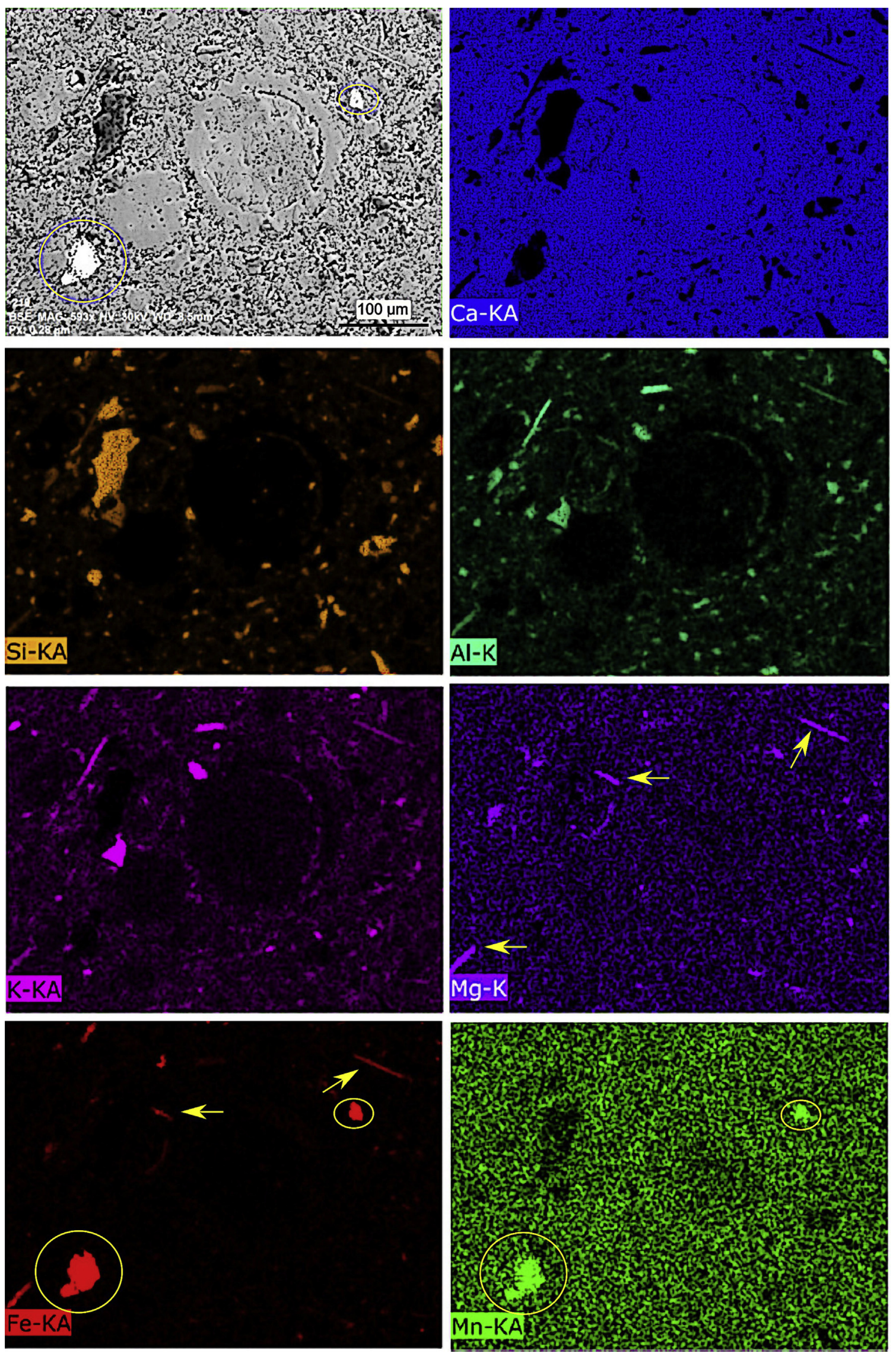

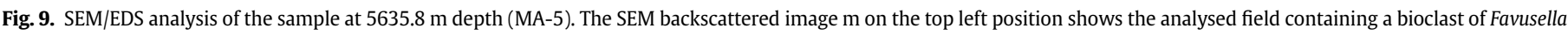

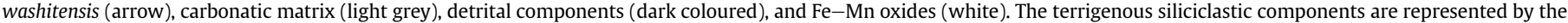

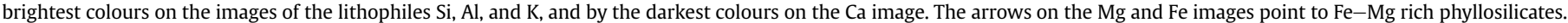
$\mathrm{Fe}-\mathrm{Mn}$ oxides are circled on the Fe and Mn images. 


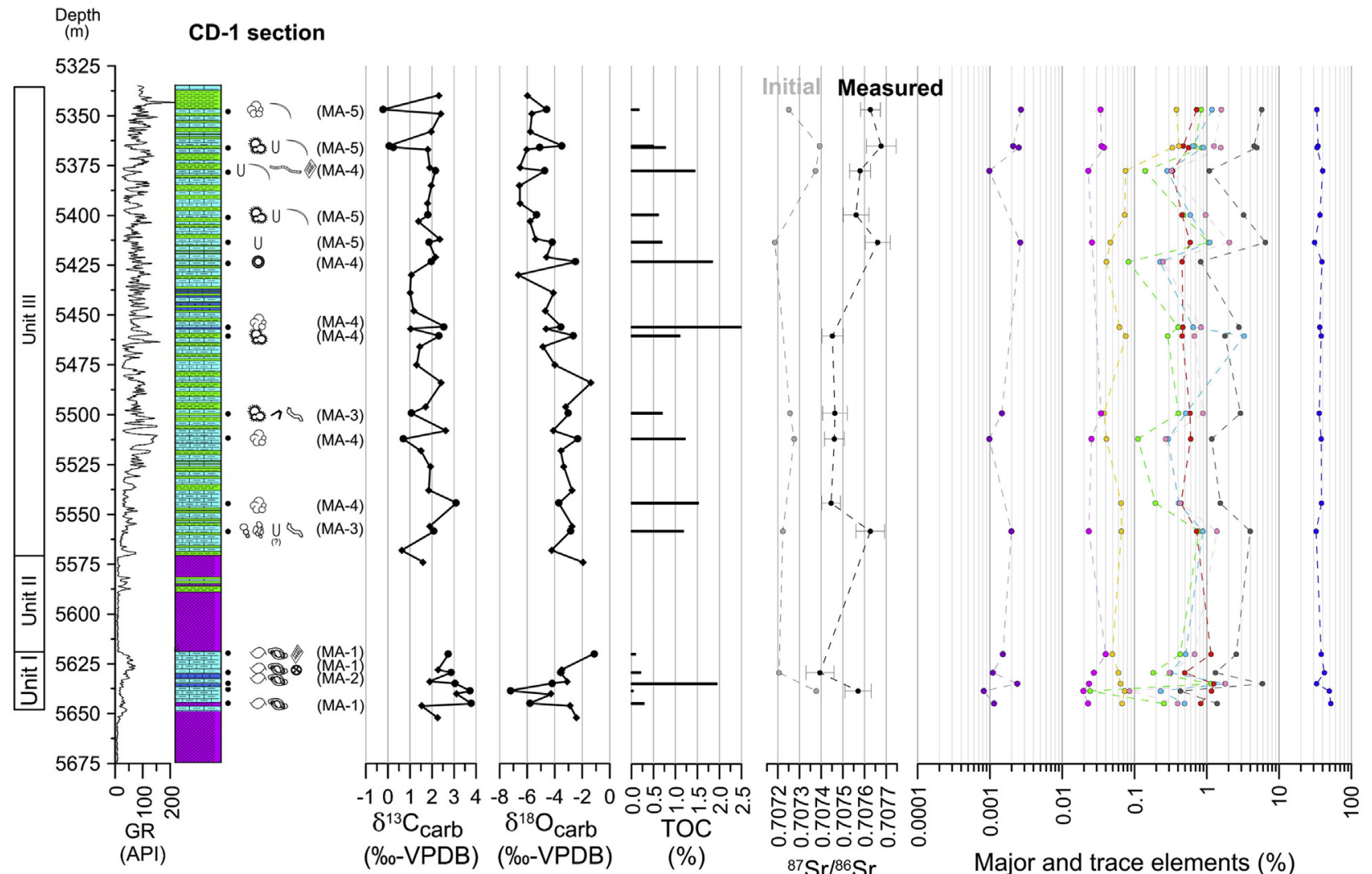

Bioclasts symbols:

\section{miliolids}

o ostracods

$\otimes$ green algae cysts

equinoid fragments

$\&$ hedbergelliform foraminifers $\uparrow$ pelagic crinoids $\checkmark$ bioturbation

$\&$ agglutinated foraminifers

8 hyaline benthic foraminifers

- pelagic calcispheres

Fig. 10. CD-1 section's chemostratigraphic profiles. $\delta^{13} \mathrm{C}$ and $\delta^{18} \mathrm{O}$ profiles are composed of sidewall samples and cuttings, whereas TOC, ${ }^{87} \mathrm{Sr} /{ }^{86} \mathrm{Sr}$, and elemental profiles are composed of sidewall samples.

MA-4, and MA-5; Fig. 10), with average and median of 1.09 and $1.10 \%$, respectively. These values are higher than the average TOC content for carbonate petroleum-source rocks $(\sim 0.6 \%$; Tissot and Welte, 1984).

In unit I, pyrolysis was only performed on a sample at $5634.9 \mathrm{~m}$ depth, with S2, $\mathrm{T}_{\max }$ and $\mathrm{HI}$ of $5.11 \mathrm{mgHC} / \mathrm{gRock}, 437{ }^{\circ} \mathrm{C}$, and
$263 \mathrm{mgHC} / \mathrm{gTOC}$, respectively (Table 3). In unit III, these parameters varied between 0.34 and $5.78 \mathrm{mgHC} / \mathrm{gRock}, 416$ to $444^{\circ} \mathrm{C}$, and 22 to $501 \mathrm{mgHC} / \mathrm{gTOC}$, respectively. HI increased from a depth of $5512.0 \mathrm{~m}$ to the top, varying from 154 to $501 \mathrm{mgHC} / \mathrm{gTOC}$, with average and median of 237 and $233 \mathrm{mgHC} / \mathrm{gTOC}$, respectively, representing well-preserved organic-matter and the potential of

Table 2

${ }^{87} \mathrm{Sr} /{ }^{86} \mathrm{Sr}$ ratios from the limestones of the $\mathrm{CD}-1$ section and calculated parameters for $\mathrm{Rb}-\mathrm{Sr}$ decay correction.

\begin{tabular}{|c|c|c|c|c|c|c|c|}
\hline & Depth $(\mathrm{m})$ & Microfacies association & $\mathrm{Rb} / \mathrm{Sr}$ & ${ }^{87} \mathrm{Sr} /{ }^{86} \mathrm{Sr}_{\text {measured }}$ & Error $(2 \sigma)$ & $\mathrm{Rb}^{87} / \mathrm{Sr}^{86}$ & ${ }^{87} \mathrm{Sr} /{ }^{86} \mathrm{Sr}_{\text {initial }}$ \\
\hline \multirow[t]{10}{*}{ Unit III } & 5346.8 & MA-5 & 0.080 & 0.70763 & 0.000046 & 0.230 & 0.70725 \\
\hline & 5365.1 & MA-5 & 0.060 & 0.70768 & 0.000069 & 0.174 & 0.70739 \\
\hline & 5377.5 & MA-4 & 0.043 & 0.70758 & 0.000048 & 0.126 & 0.70737 \\
\hline & 5399.6 & MA-5 & - & 0.70756 & 0.000060 & - & - \\
\hline & 5413.5 & MA-5 & 0.100 & 0.70766 & 0.000058 & 0.290 & 0.70719 \\
\hline & 5460.4 & MA-4 & - & 0.70745 & 0.000049 & - & - \\
\hline & 5499.1 & MA-3 & 0.044 & 0.70746 & 0.000057 & 0.126 & 0.70726 \\
\hline & 5512.0 & MA-4 & 0.039 & 0.70746 & 0.000045 & 0.113 & 0.70728 \\
\hline & 5544.2 & MA-5 & - & 0.70745 & 0.000043 & - & - \\
\hline & 5558.3 & MA-3 & 0.085 & 0.70763 & 0.000066 & 0.247 & 0.70722 \\
\hline \multirow[t]{2}{*}{ Unit I } & 5629.3 & MA-1 & 0.040 & 0.70739 & 0.000065 & 0.116 & 0.70721 \\
\hline & 5638.5 & MA-1 & 0.041 & 0.70757 & 0.000060 & 0.118 & 0.70738 \\
\hline
\end{tabular}

Notes: (-) not calculated. 
Table 3

TOC, insoluble residues, $\mathrm{S} 2, \mathrm{~T}_{\max }$, and $\mathrm{HI}$ data from the limestones of the CD-1 section.

\begin{tabular}{|c|c|c|c|c|c|c|c|}
\hline & Depth (m) & Microfacies association & TOC (\%) & Insoluble residue & $\mathrm{S} 2$ (mgHC/gRock) & $\operatorname{Tmax}\left({ }^{\circ} \mathrm{C}\right)$ & HI (mgHC/gTOC) \\
\hline \multirow[t]{13}{*}{ Unit III } & 5346.8 & MA-5 & 0.17 & 23.41 & n.a. & n.a. & n.a. \\
\hline & 5365.1 & MA-5 & 0.50 & 17.81 & 1.16 & 429 & 233 \\
\hline & 5365.8 & MA-5 & 0.77 & 20.56 & 1.24 & 428 & 160 \\
\hline & 5377.5 & MA-4 & 1.44 & 10.04 & 3.44 & 416 & 239 \\
\hline & 5399.6 & MA-5 & 0.61 & 13.20 & 1.42 & 437 & 233 \\
\hline & 5413.3 & MA-5 & 0.69 & 14.74 & 3.46 & 432 & 501 \\
\hline & 5423.2 & MA-4 & 1.84 & 12.75 & 2.84 & 437 & 154 \\
\hline & 5456 & MA-4 & 2.49 & 18.40 & 5.78 & 440 & 232 \\
\hline & 5460.4 & MA-4 & 1.10 & 14.98 & 2.62 & 436 & 238 \\
\hline & 5499.1 & MA-3 & 0.70 & 13.10 & 2.51 & 436 & 361 \\
\hline & 5512 & MA-4 & 1.22 & 6.02 & 5.41 & 421 & 443 \\
\hline & 5544.2 & MA-4 & 1.52 & 16.00 & 0.34 & 444 & 22 \\
\hline & 5558.3 & MA-3 & 1.18 & 19.05 & 0.36 & 441 & 31 \\
\hline \multirow[t]{5}{*}{ Unit I } & 5620 & MA-1 & 0.09 & 9.56 & n.a. & n.a. & n.a. \\
\hline & 5629.3 & MA-1 & 0.21 & 4.37 & n.a. & n.a. & n.a. \\
\hline & 5634.9 & MA-2 & 1.94 & 37.45 & 5.11 & 437 & 263 \\
\hline & 5638.5 & MA-2 & 0.04 & 1.99 & n.a. & n.a. & n.a. \\
\hline & 5644.8 & MA-1 & 0.28 & 4.38 & n.a. & n.a. & n.a. \\
\hline
\end{tabular}

(n.a.) not analysed.

unit III for oil generation. $\mathrm{T}_{\max }$ values are close to the initial oil and gas window, but the average and median of this unit of 433 and $436{ }^{\circ} \mathrm{C}$, respectively, did not reach this range.

\section{Discussions}

\subsection{Assessing diagenetic alteration of carbonates}

Significant attention is required when using $\mathrm{C}$ and $\mathrm{O}$ stable isotopes and ${ }^{87} \mathrm{Sr} /{ }^{86} \mathrm{Sr}$ ratios in carbonates chemostratigraphy and paleoenvironmental studies, to determine the role of diagenetic overprinting on primary signals (e.g. Hudson, 1977; Scholle and Arthur, 1980; Banner, 2004). For carbon and oxygen, meteoric diagenesis presents a higher potential for alteration of depositional marine carbonates signatures, leading to lighter isotope compositions. To assess this potential, a $\delta^{13} \mathrm{C} v s \delta^{18} \mathrm{O}$ diagram is typically used, in which a positive correlation suggests meteoric overprinting (Hudson, 1977; Veizer et al., 1999).

None of the units present positive correlation between $\delta^{13} \mathrm{C}$ and $\delta^{18} \mathrm{O}$ (Fig. 11A). Unit I presents a negative correlation between $\delta^{13} \mathrm{C}$ and $\delta^{18} \mathrm{O}(\mathrm{r}=-0.72)$, whereas unit III shows no correlation between $\delta^{13} \mathrm{C}$ and $\delta^{18} \mathrm{O}(\mathrm{r}=0.00)$, suggesting a lack of meteoric diagenesis in the studied section. In unit I, the two most basal sidewall samples (depths 5644.8 and $5638.5 \mathrm{~m}$ ) showed intense recrystallization (Fig. 4) and the lowest $\delta^{18} \mathrm{O}$ and highest $\delta^{13} \mathrm{C}$ values. The first parameter can be explained by an influence of high temperature fluids in a burial diagenetic setting, considering the greater susceptibility of oxygen isotopes to post-depositional changes (Hudson, 1977). On the other hand, there is no simple explanation for the highest $\delta^{13} \mathrm{C}$ values in these samples related to post-depositional alteration. Diagenetic processes that can lead to an increase in carbonates $\delta^{13} \mathrm{C}$ are known, such as in methanogenic environments (e.g. Meister et al., 2011; Birgel et al., 2015), but it is difficult to assume influence of this process without more specific analysis.

In addition to a positive correlation between $\delta^{13} \mathrm{C} v s \delta^{18} \mathrm{O}$, the influence of diagenetic fluids can lead to increasing concentrations of $\mathrm{Mn}$ in marine carbonates, as well as the preferential leaching of $\mathrm{Sr}$ in relation to $\mathrm{Ca}$ (Brand and Veizer, 1980; Banner and Hanson, 1990). The relationship between $\mathrm{Mn}$ and $\mathrm{Sr} / \mathrm{Ca}$ shows that both units follow the initial trend expected for diagenetic alteration, however without significant increase in Mn content (Fig. 11B; e.g. Brand and Veizer, 1980). The highest Mn contents were not considered in this evaluation, due to the fact that these values are associated with oxides in these samples (see circled samples in Fig. 11B; MA-5 - Fig. 9, depths $5346.8,5365.1$ and $5365.8 \mathrm{~m}$ ), clearly contrasted with other samples from unit III. Despite these, the two basal sidewall samples from unit I (depths 5644.8 and $5638.5 \mathrm{~m}$ ) had the lowest $\mathrm{Sr} / \mathrm{Ca}$ ratios accompanied by higher Mn contents, due to intense recrystallization.

$\mathrm{Mn}$ incorporation in marine carbonates is related both to meteoric diagenesis as to (re)precipitation under reducing conditions, either in early marine or late burial diagenesis environments (Brand and Veizer, 1980; Veizer, 1983). Following the evaluation presented by Kah (2000), the $\delta^{18} \mathrm{O}$ vs [Mn] diagram (Fig. 11C) was used to distinguish the different conditions associated with the increase in Mn contents and potential diagenetic fluids. In unit I, the increase in Mn content is coupled with a decrease in $\delta^{18} \mathrm{O}$ values $(\mathrm{r}=-0.99$; Fig. 11C), as expected for meteoric fluids, whereas in unit III the Mn increase was not related to significant decrease in $\delta^{18} \mathrm{O}$ values $(\mathrm{r}=-0.50$; Fig. $11 \mathrm{C}$ ), following the trend for brines (Kah, 2000). Despite unit I presents a strongly negative correlation between $\delta^{18} \mathrm{O}$ and [Mn], a positive correlation between $\delta^{13} \mathrm{C}$ and $\delta^{18} \mathrm{O}$, as expected for meteoric diagenesis, was not found, as discussed previously. Thus, another possible interpretation for the diagenetic environment is recrystallization associated with brines under reducing conditions, and the relationship between lighter $\delta^{18} \mathrm{O}$ values and higher temperatures of recrystallization, such as in burial diagenesis. In unit III, the Mn increase may be related to an early reducing marine diagenesis, considering the weaker negative correlation between $\delta^{18} \mathrm{O}$ and [Mn], increased TOC contents and pyrite framboids.

Post-depositional alteration of carbonate ${ }^{87} \mathrm{Sr} /{ }^{86} \mathrm{Sr}$ ratios are related to radiogenic ${ }^{87} \mathrm{Sr}$ contributions from terrigenous minerals and the loss of $\mathrm{Sr}$ during diagenesis (Banner, 1995). Radiogenic decay of ${ }^{87} \mathrm{Rb}$ to ${ }^{87} \mathrm{Sr}$ affects mainly limestones with high $\mathrm{Rb} / \mathrm{Sr}$, i.e., those with high terrigenous contents. Additionally, the lower the $\mathrm{Sr}$ content, the higher the ${ }^{87} \mathrm{Sr} /{ }^{86} \mathrm{Sr}$ ratio alteration, even under lower fluid/rock ratios (Banner and Hanson, 1990).

The $\mathrm{Rb} / \mathrm{Sr} v \mathrm{~s}^{87} \mathrm{Sr} /{ }^{86} \mathrm{Sr}$ shows a positive correlation $(\mathrm{r}=0.72)$ between these parameters (Fig. 12A), suggesting that radiogenically derived ${ }^{87} \mathrm{Sr}$ may have influenced the $\mathrm{Sr}$ isotope compositions. In fact, the most radiogenic ratios are found in limestones from MA-5, with the highest terrigenous content (Fig. 8; Table 2). Despite the corrected ${ }^{87} \mathrm{Sr} /{ }^{86} \mathrm{Sr}_{\text {initial }}$ ratios being in agreement with latest late Aptian-early Albian reference values and biostratigraphic content, as will be discussed in section 5.3 , this does not necessarily imply 

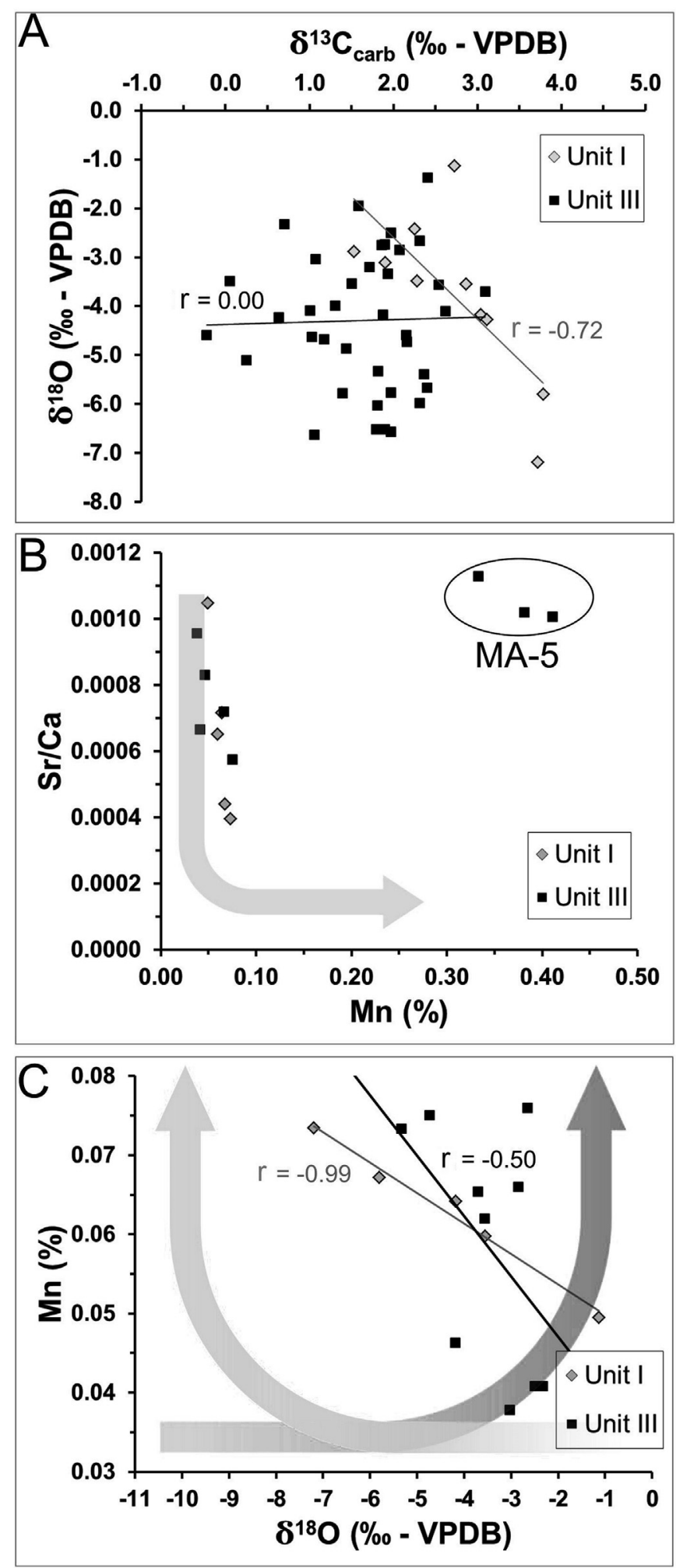

Fig. 11. Geochemical diagrams for the limestones from units I and III. A) $\delta^{13} \mathrm{C}_{\text {carb }} v s$ $\delta^{18} \mathrm{O}$. B) [Mn] vs Sr/Ca diagram, based on Kah (2000), in which the light grey arrow represents interaction with non-marine fluids. The three circled samples correspond to MA-5, in which Mn-Fe contents are related to Fe-Mn oxides and were not considered in this evaluation. C) $\delta^{18} \mathrm{O} v s[\mathrm{Mn}]$ diagram, based on Kah (2000), in which light grey arrow shows the diagenetic alteration trend related to fresh water or meteoric fluids, whereas the dark grey arrow shows the alteration trend for brines.
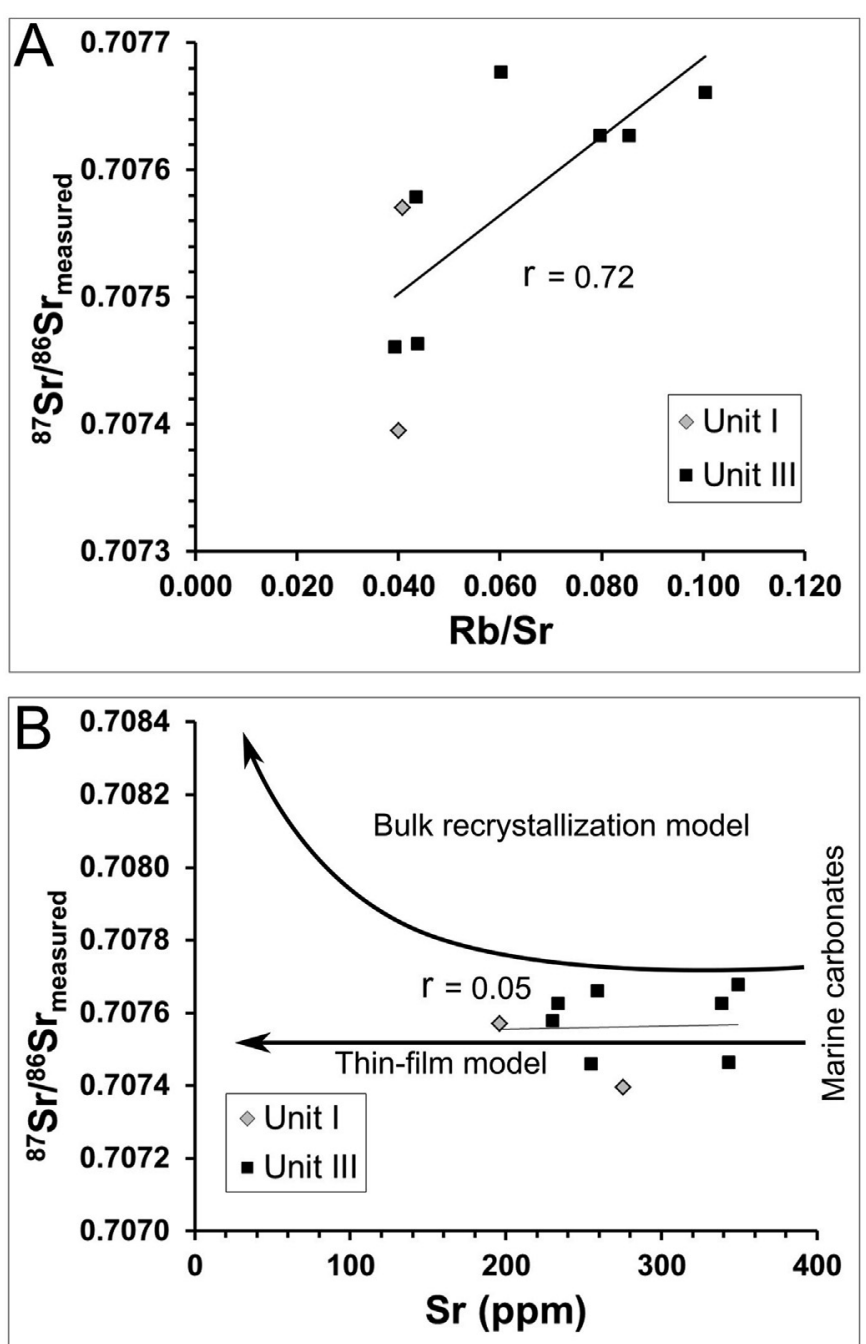

Fig. 12. ${ }^{87} \mathrm{Sr} /{ }^{86} \mathrm{Sr}$ ratios geochemical diagrams. A) $\mathrm{Rb} / \mathrm{Sr} v{ }^{87} \mathrm{Sr} /{ }^{86} \mathrm{Sr}$ shows a positive correlation, which suggests that the ${ }^{87} \mathrm{Sr} /{ }^{86} \mathrm{Sr}$ ratios of the analysed carbonates may have been influenced by the terrigenous content. B) $[\mathrm{Sr}] v s^{87} \mathrm{Sr} /{ }^{86} \mathrm{Sr}$ diagram shows no correlation between these parameters. Models for $\mathrm{Sr}$ diagenetic evolution presented by Banner (1995) and references therein.

that the ${ }^{87} \mathrm{Sr} /{ }^{86} \mathrm{Sr}_{\text {measured }}$ ratios (approximately 0.0003 more radiogenic) are altered. The central South Atlantic paleogeography in this stage resulted in restricted marine circulation patterns (Koutsoukos et al., 1991; Dias-Brito, 2000; Azevedo, 2004; Arai, 2014). Hence, considering the factors that control the ocean $\mathrm{Sr}$ isotope compositions (e.g. Palmer and Edmond, 1992; Jones and Jenkyns, 2001; Banner, 2004), the proposed paleogeographic scenario would imply more effective contributions from more radiogenic ${ }^{87} \mathrm{Sr} /{ }^{86} \mathrm{Sr}$ continental waters rather than a less radiogenic ${ }^{87} \mathrm{Sr} /{ }^{86} \mathrm{Sr}$ hydrothermal influx (e.g. Huber et al., 2011). The early South Atlantic was completely surrounded by older continental rocks from the eastern Brazilian and western African margins (Fig. 1), while the oceanic crust production and spreading just started.

An additional evaluation of the ${ }^{87} \mathrm{Sr} /{ }^{86} \mathrm{Sr}$ ratios concerns about the $\mathrm{Sr}$ loss during diagenesis, given the low $\mathrm{Sr}$ content of these limestones (Table 1). Here, we examine the $[\mathrm{Sr}] v{ }^{87} \mathrm{Sr} /{ }^{86} \mathrm{Sr}$ diagram (Fig. 12B), based on models discussed by Banner (1995). Two models for ion exchange between pore fluids and carbonate grains during diagenesis were presented. The bulk recrystallization model 
(Morrow and Mayers, 1978) represents ion exchange through advection between grains and fluids, under high pore fluid volumes, whereas in the thin-film model (e.g. Veizer, 1978) $\mathrm{Sr}$ is exchanged through diffusion with fluids in micropore environments. Banner (1995) presented calculations for these models and showed that each one had a different $[\mathrm{Sr}] v{ }^{87} \mathrm{Sr} /{ }^{86} \mathrm{Sr}$ pathway (Fig. 12B). In the bulk recrystallization model the loss of $\mathrm{Sr}$ is accompanied by an increase of ${ }^{87} \mathrm{Sr} /{ }^{86} \mathrm{Sr}$ ratios, due to ion exchange, whereas, in contrast, in the thin-film model this relationship is not observed, with residual $\mathrm{Sr}$ isotope compositions remaining constant, as long as the pore fluids have lower $\mathrm{Sr}$ concentrations than the carbonates. This seems to be the case of ${ }^{87} \mathrm{Sr} /{ }^{86} \mathrm{Sr}$ ratios of the limestones analysed in the $\mathrm{CD}-1$ section, given the lack of correlation between $\mathrm{Sr}$ and ${ }^{87} \mathrm{Sr} /{ }^{86} \mathrm{Sr}(\mathrm{r}=0.05$; Fig 12B). Thus, regardless of low $\mathrm{Sr}$ contents from the limestones from the CD-1 section, the ${ }^{87} \mathrm{Sr} /{ }^{86} \mathrm{Sr}$ ratios obtained are not necessarily altered by $\mathrm{Sr}$ loss during diagenesis. Only the sample at $5638.5 \mathrm{~m}$ depth was discarded from discussions, due to a high intensity of recrystallization processes and a higher loss of $\mathrm{Sr}$ (Table 2, Fig. 12B).

In summary, based on this geochemical evaluation and microfacies analysis, a diagenetic evolution from reducing early marine diagenesis to burial diagenesis is proposed, in which the basal unit I was more intensely altered, due to the higher compaction and higher carbonate content of these rocks, as presented in section 4.1. Organic-rich limestones and an abundance of pyrite framboids in unit III are in agreement with reducing conditions of early marine diagenesis. Both diagenetic environments are, however, believed to have preserved its carbon and strontium isotope compositions, as the fluids are derived from seawater in early marine diagenesis and the progressive compaction of pelagic limestones obliterates the porosity, and fluid/rock interaction occurs at low ratios (Hudson, 1977; Scholle and Arthur, 1980; Renard, 1986).

\subsection{Integrating microfacies and geochemical data: paleoenvironmental model}

The microfacies associations align with a carbonate ramp model (Fig. 13), following the proposal for early marine stages in the Campos Basin (e.g. Guardado et al., 1989). As mentioned earlier, MA-1 and 2 (unit I) are composed of shallower marine facies, whereas MA-3, 4 and 5 (unit III) represent deeper portions of the ramp, although still reflecting a neritic environment.

MA-1 were deposited in an inner ramp, low-energy environment (Fig. 13), as it is represented by bioclastic wackestones containing miliolids and articulated ostracodes in a micritic matrix with negligible terrigenous contents (Fig 4). The relative abundance of benthic taxa and low TOC contents suggests an oxygenated environment.

Peloid/bioclastic packstone and wackestone from MA-2 (unit I; Fig. 5) was associated with the flank of a carbonate bank (Fig. 13). This microfacies suggests some agitation and moderate energy as well as some continental input based on locally terrigenous laminations. The presence of ooids in wackestone microfacies led to the inference of an oolitic bank, from which these grains would be transported. Terrigenous laminations represent episodic

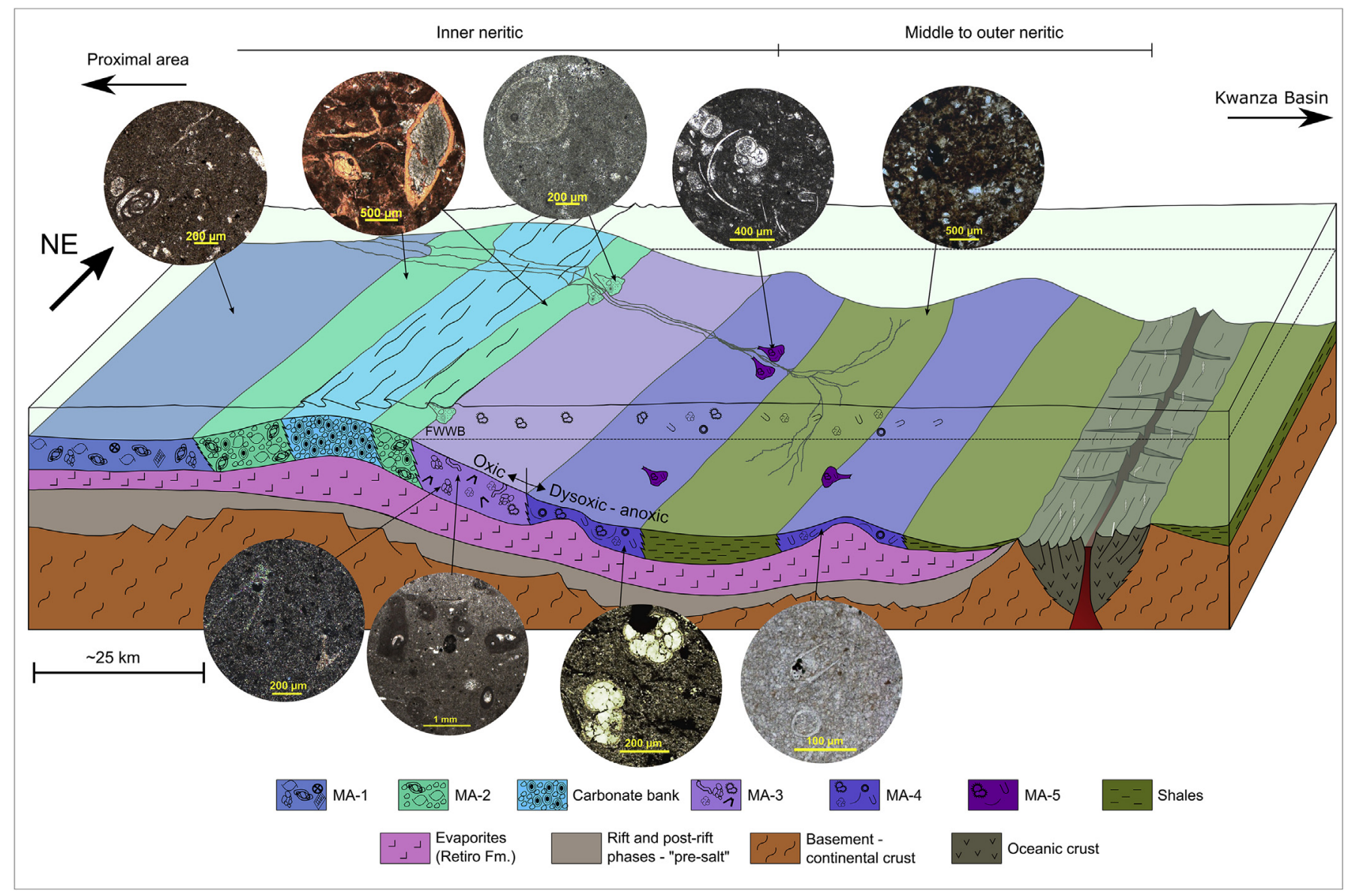

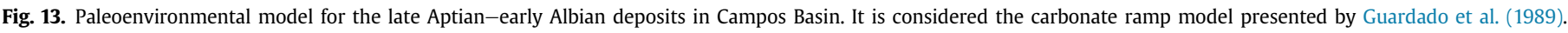
FWWB - Fair-Weather Wave Base. Bioclasts legend was given in Fig. 3. 
continental input and probably are responsible for high TOC in this microfacies (Table 3 ).

Towards the more distal portions of the ramp, MA-3 (unit III, Fig. 6) corresponds to an inner-middle neritic environment (Fig. 13), presenting a lower frequency of benthic organisms and some bioturbations structures. The presence of agglutinated foraminifers suggests moderate to low energy. The less abundant pelagic microcrinoids and planktic foraminifers characterize a deeper and more distal domain as compared to MA-1 and 2. Therefore, this microfacies association was positioned under the fair-weather wave base level (FWWB; Fig. 13). An oxic environment was interpreted based on the presence of bioturbations and benthic biota in microfacies analysis. However, even in well-oxygenated bottom water conditions the TOC contents are relatively high (TOC of 1.18 and $0.70 \%$, Table 3 ), considering carbonate rocks. This unusual association suggests other factors contributing to organicmatter preservation, such as enhanced bioproductivity, as discussed below.

MA-4 (Fig. 7) was deposited under middle to outer neritic environment (Fig. 13), given the relative large tests of $F$. washitensis, up to $200-250 \mu \mathrm{m}$, with well-developed ornamentation, pointing to the most distal area of distributions of this planktic foraminifer (Hart and Koutsoukos, 2015). Microfacies that are dominated by Colomiella recta and lack Favusella spp. were assumed to be indicative of outer neritic environments (Fig. 13). A low-energy environment is interpreted for this microfacies, given the matrix composed of micrite and nannofossils. The highest TOC contents were found in this microfacies association (1.10-2.49\%; Table 3). Based on the absence of benthic organisms and the abundance of pyrite framboids, MA-4 was deposited under suboxic-anoxic bottom conditions, where bacterial sulphate-reduction was the main early diagenetic oxidizing process.

MA-5 represents tempestites, as allochthonous deposits accumulated under middle to outer neritic environment (Fig. 13). This is based on the abundance of planktic bioclasts and the co-occurrence of glauconite grains, $\mathrm{Fe}-\mathrm{Mn}$ oxides and pyrite framboids in the matrix (Fig. 8 and 9), as transported sediments from more proximal and oxygenated bottom environments to deeper oxygen-depleted portions of the basin. TOC contents are lower than those obtained for MA-4; however they are still high for carbonate rocks (up to $0.77 \%$ ), leading to the same interpretations developed for MA-3. Very similar microfacies were described in the southeastern Brazilian margin basins, also interpreted as facies containing transported sediments (Carvalho et al., 1999; Dias-Brito and Ferré, 2001; Dias-Brito, 2002).

Unit III corresponds to high frequency intercalations of limestones and shales, as demonstrated by the gamma ray log and cuttings (Fig. 3B). Only one shale sidewall sample was recovered and no fossils were observed in this facies, which is composed of an organic clay-silty matrix (Fig. 13). This lithological intercalation between fine-grained limestones and shales may represent a lysocline variation where shales were deposited in the depocentre of platform, controlled by halokinesis (Fig. 13).

Regarding the increased TOC contents found in carbonate rocks of MA-3 and MA-5 (>0.5\%; Table 3), some features related to oxygenated bottom conditions are present (benthic biota, bioturbation and Fe-Mn oxides; Figs. 6, 8, and 9) and suggest that redox conditions did not play a primary role on the deposition of organic-rich limestones from unit III. We interpret that enhanced bioproductivity may have been the main factor controlling organicmatter accumulation and preservation. On the other hand, MA-4 presented the highest TOC values and was characterized as deposited under dysoxic-anoxic bottom conditions. In this case, high bioproductivity associated with oxygen-depleted bottom conditions may have enhanced organic-matter preservation. The increase in productivity can lead to the development of dysoxic-anoxic conditions, as the increase in organic-matter flux stimulates the oxic degradation processes, resulting in $\mathrm{O}_{2}$ exhaust (e.g. Jenkyns, 2010).

\subsection{Age constraints for the $C D-1$ section}

The occurrence of the colomiellid Colomiella recta allowed a preliminary age assignment for the studied section. Colomiellids are considered as reasonable index fossils due to their wide geographic distribution and relatively short temporal duration (Dias-Brito, 2002). Colomiella recta was described from several locations within the Tethyan Realm, such as the Gulf of Mexico, northeast Mexico, Cuba, Tunisia, the western Carpathians, the Zagros Mountains (Southwest Iran), and from other basins in the Central South Atlantic (Chevalier and Fischer, 1982; Premoli-Silva and McNulty, 1984; Blanco-Bustamante, 2001; Dias-Brito, 2002; Longoria and Monreal, 2009; Chihaoui et al., 2010; Vincent et al., 2010; Michalík et al., 2012).

In most recent biostratigraphic studies, $C$. recta is assigned to the upper Aptian to lower Albian interval (e.g. Premoli-Silva and McNulty, 1984; Dias-Brito, 1999; Blanco-Bustamante, 2001; DiasBrito and Ferré, 2001; González-León et al., 2008; Longoria and Monreal, 2009; Vincent et al., 2010; Michalík et al., 2012; NúñesUseche and Barragán, 2012; Madhavaraju et al., 2013; Núñez-Useche et al., 2016). Based on the study of Longoria (1984), Longoria and Monreal (2009) updated Mexico's mid-Cretaceous biochronostratigraphy, positioning the occurrence of the genus Colomiella from the late Aptian to the early Albian, in which Favusella spp. also occurred. Núñez-Useche and Barragán (2012) reported the first occurrence of $C$. recta within an interval containing late Aptian ammonites in northeast Mexico, assigning the colomiellid to the late Aptian-early Albian interval. Recently, Núñez-Useche et al. (2016) presented an integrated microfacies analysis and chemostratigraphy for the Francisco Zarco Dam section (NE Mexico) and positioned C. recta inside of Mexicana subzone (Trejo, 1975), late Aptian-early Albian in age. The first occurrence of $C$. recta marks the late Aptian-early Albian boundary in this section, above a ${ }^{87} \mathrm{Sr} /{ }^{86} \mathrm{Sr}$ minimum of $\sim 0.7072$ within the latest late Aptian.

In the central South Atlantic, colomiellids were described at the eastern Brazilian (Dias-Brito, 1995, 2002; Carvalho et al., 1999; Dias-Brito and Ferré, 2001) and the western African margins (Chevalier and Fischer, 1982). Dias-Brito (1999) limited the Colomiella recta interval zone to the early Albian in the southeastern Brazilian margin, based on the biochronostratigraphy so far available from the Mexico region. Its lower limit is marked by the extinction of $C$. mexicana (upper Aptian), while the upper limit is associated with the extinction of $C$. recta. Thereafter, Dias-Brito and Ferré (2001) assigned the association of Colomiella, Favusella and Microcalamoides diversus, described in the southeastern Brazilian margin, to the early Albian, close to the late Aptian-early Albian boundary.

The isotopic data obtained from $\mathrm{CD}-1$ section are consistent with the age assignment of the studied interval as late Aptian to early Albian. Recently, Bodin et al. (2015) presented C, O and Sr isotope curves based on new and compiled data from the Vocontian Basin (SE France; VB; Figs. 1 and 14), which was time calibrated against Gradstein et al.'s (2012) Time Scale. C and Sr isotope data from CD-1 section fit the latest late Aptian-early Albian interval of the isotope profiles provided by these authors. A general radiogenic trend observed in the ${ }^{87} \mathrm{Sr} /{ }^{86} \mathrm{Sr}_{\text {initial }}$ profile, from 0.7072 to 0.7074 , is only found in the late Berriasian-late Valanginian and the latest late Aptian-early Albian intervals of the Early Cretaceous ${ }^{87} \mathrm{Sr} /{ }^{86} \mathrm{Sr}$ reference curves (Bralower et al., 1997; Jones and Jenkyns, 2001; Bodin et al., 2015). The available data was adjusted to the latter 


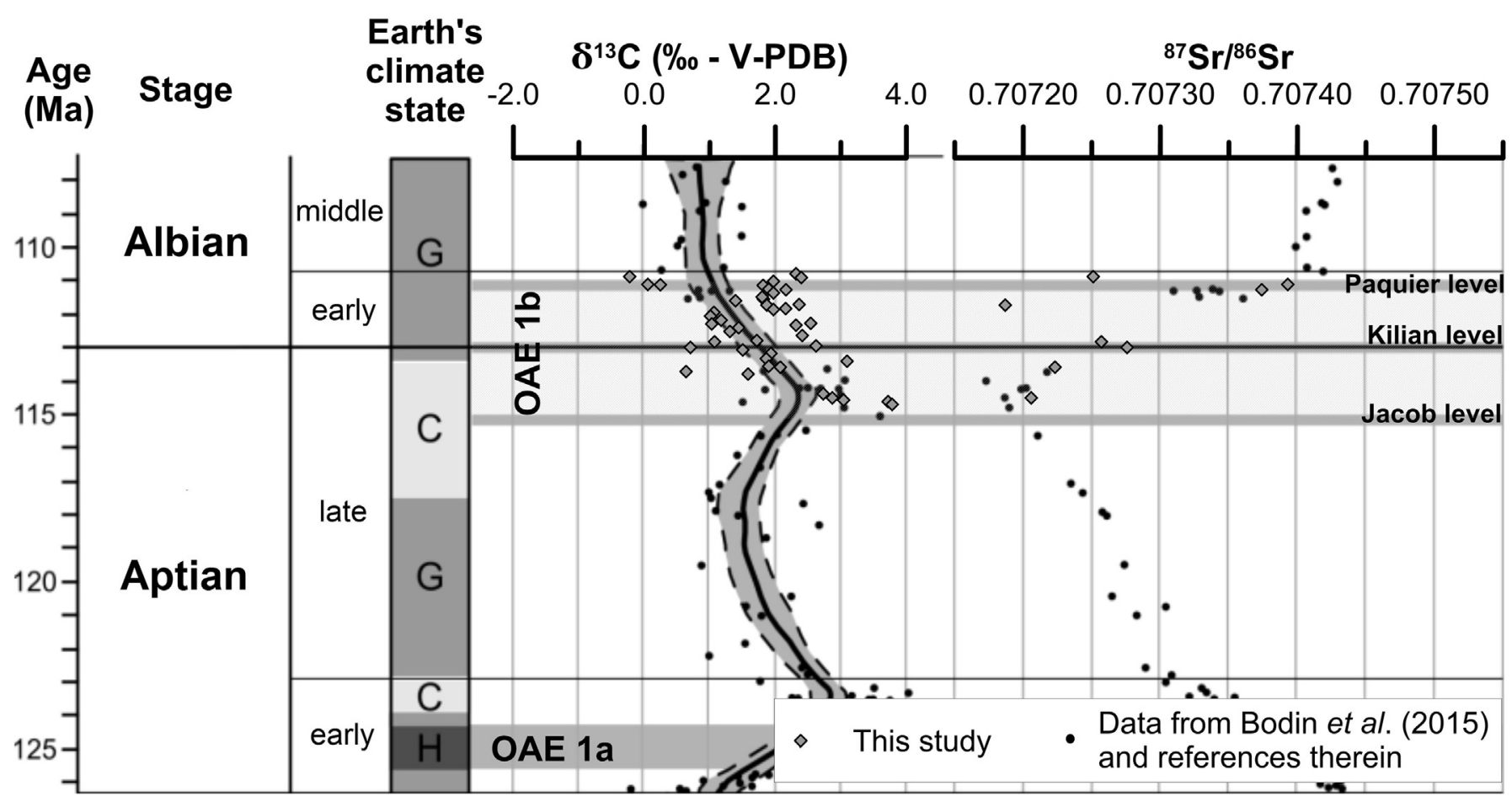

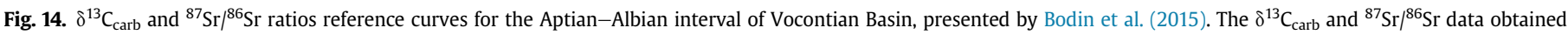

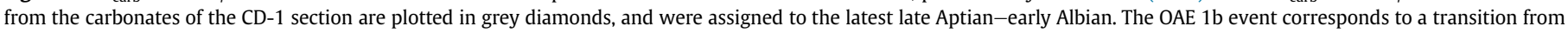
coldhouse (C) to greenhouse stage (G), according to Bodin et al. (2015).

interval based on isotopic trends and ${ }^{87} \mathrm{Sr} /{ }^{86} \mathrm{Sr}_{\text {initial }}$ values, in agreement with biostratigraphic data discussed above, representing an interval of rapid increase in oceanic $\mathrm{Sr}$ ratios in the Cretaceous.

The ${ }^{87} \mathrm{Sr} /{ }^{86} \mathrm{Sr}_{\text {initial }}$ trend of $\mathrm{CD}-1$ fits very well for this time interval in the ${ }^{87} \mathrm{Sr} /{ }^{86} \mathrm{Sr}$ curves. The only exceptions were samples at 5413.5 and $5346.8 \mathrm{~m}$ depth, with less radiogenic values compared to the ${ }^{87} \mathrm{Sr} /{ }^{86} \mathrm{Sr}$ curves (Fig. 14). These samples correspond to tempestites (MA-5; Fig. 8) that may represent reworked older sediments. Regarding the $\delta^{13} \mathrm{C}_{\text {carb }}$ profile, it matches the general long-term negative excursion through late Aptian-early Albian transition (Fig. 14). The distinct feature of CD-1 is the higher amplitude of $\delta^{13} \mathrm{C}_{\text {carb }}$ variations, which can be associated with the condition of a restricted sea, representing a smaller reservoir with higher variability compared to coeval open marine settings.

\subsection{Organic-rich deposits of the early South Atlantic Ocean and the} $O A E 1 b$

Oceanic anoxic events represent major perturbations in the global carbon cycle due to drastic changes in paleoclimate and paleoceanography (e.g., Erbacher et al., 1999, 2001; Herrle et al., 2004; Föllmi et al., 2006; Jenkyns, 2010; Huber et al., 2011; Föllmi, 2012; Coccioni et al., 2014). Although the concept was introduced 40 years ago (Schlanger and Jenkyns, 1976), the driving forces responsible for these events are still disputed. The most recent studies pointed to enhanced greenhouse conditions, due to $\mathrm{CO}_{2}$ input by volcanic or methanogenic sources (e.g. Jenkyns, 2010). Because of enhanced global warming and a more active hydrologic cycle, continental weathering was increased, leading to higher nutrient input into various basins, and consequently higher productivity (e.g. Erbacher et al., 1999; Browning and Watkins, 2008; Jenkyns, 2010). As another consequence, $\mathrm{O}_{2}$ demand in the water column was increased by biochemical oxidation processes, in response to the higher organic flux. The progressive $\mathrm{CO}_{2}$ removal through chemical weathering and organic-matter burial would lead to climate cooling, but with remarkable geochemical changes occurring at a scale of hundreds of thousands of years (Jones and Jenkyns, 2001; Jenkyns, 2010).

Given a latest late Aptian-early Albian age for CD-1 section, the association of organic-rich limestones from unit III with the major ocean-climatic perturbations related to $\mathrm{OAE} 1 \mathrm{~b}$ is quite reasonable. Here, we use the concept of $\mathrm{OAE} 1 \mathrm{~b}$ as an interval encompassing four organic-rich levels through the late Aptian-early Albian transition (Jacob, Kilian, Paquier/Urbino, Leenhardt; 114-109 Ma; Leckie et al., 2002; Föllmi et al., 2006; Coccioni et al., 2014; Sabatino et al., 2015), consisting in a longer term event as compared to OAE $1 \mathrm{a}$ and 2 . Another feature of OAE $1 \mathrm{~b}$ is that the $\delta^{13} \mathrm{C}_{\text {carb }}$ positive excursions often associated with organic-rich intervals (e.g. Scholle and Arthur, 1980) are more variable and not so easy to identify compared to the other referred oceanic anoxic events. Instead, this interval corresponds to a long-term $\delta^{13} C_{\text {carb }}$ negative excursion $(\sim 4 \mathrm{Myr})$ which comprises a set of complex $\delta^{13} \mathrm{C}_{\text {carb }}$ negativepositive excursions varying according to paleogeography and paleoceanographic conditions (Herrle et al., 2004; Jenkyns, 2010; Trabucho-Alexandre et al., 2011; Föllmi, 2012; Coccioni et al., 2014; Sabatino et al., 2015).

As presented above, the rapid increasing trend of ${ }^{87} \mathrm{Sr} /{ }^{86} \mathrm{Sr}$ ratios through the late Aptian-early Albian transition, first time recognized in South Atlantic by the present study, can be considered another isotopic signature for OAE 1b interval (Jones and Jenkyns, 2001; Leckie et al., 2002; Bodin et al., 2015). Whether volcanic activity, hydrothermal influx, and/or oceanic crust production (Jones and Jenkyns, 2001) or decreasing weathering rates (Bodin et al., 2015) were the trigger for the decreasing ${ }^{87} \mathrm{Sr} /{ }^{86} \mathrm{Sr}$ ratios along the Aptian, it seems to be accepted that increasing continental weathering rates were responsible for the increasing ${ }^{87} \mathrm{Sr} /{ }^{86} \mathrm{Sr}$ ratios during OAE $1 \mathrm{~b}$ (late Aptian to early Albian; Jones 
and Jenkyns, 2001; Jenkyns, 2010; Bodin et al., 2015). This trend could result from an enhanced greenhouse stage in a scenario that matches the evolution observed in unit III, with rapid radiogenic increase of the ${ }^{87} \mathrm{Sr} /{ }^{86} \mathrm{Sr}$ ratios and increase of continental influx at the top of the sequence (MA-5; Figs. 9, 10, and 14). Recently, NúñezUseche et al. (2016) presented data from NE Mexico, in which OAE $1 \mathrm{~b}$ set corresponds to an interval of shaly limestones and shales containing increased TOC contents (up to 7.5\%) through the radiogenic ${ }^{87} \mathrm{Sr} /{ }^{86} \mathrm{Sr}$ trend from $\sim 0.7072$ to 0.7073 and a long-term $\delta^{13} C_{\text {carb }}$ negative excursion. An increase in terrigenous detrital input was also observed in this section, interpreted as a response to warm and humid conditions. This succession is very similar to CD-1, regarding microfacies content, $\delta^{13} \mathrm{C}_{\text {carb }}$ and ${ }^{87} \mathrm{Sr} /{ }^{86} \mathrm{Sr}$ evolution.

Due to the CD-1's low-resolution sampling compared to sequences studied in outcrop, as it relies on cuttings (interval sampling) and scattered sidewall samples provided by a petroleum exploration well, the identification of the different organic rich levels which compose OAE $1 \mathrm{~b}$ was not possible. This did not allow a proper high-resolution correlation with a reference section, so we assume here the possibility that unit III overpasses the OAE $1 \mathrm{~b}$ levels and encompasses the 'OAE 1b set' (e.g. Föllmi et al., 2006; Núñez-Useche et al., 2016) in CD-1. Besides sampling resolution limitations, another explanation for the difficulty in identifying each organic-rich level of OAE $1 \mathrm{~b}$ is that the high frequency limestone-shale cycles may represent the particular expression of OAE $1 \mathrm{~b}$ in the early central South Atlantic (e.g. Trabucho-Alexandre et al., 2011), as a result of different sedimentation rates and climate conditions (warm and dry; Dias-Brito and Azevedo, 1986) compared to northern regions.

Organic-rich intervals were identified by previous studies in the late Aptian-early Albian earliest marine phases of the South Atlantic Ocean (Bolli et al., 1978; Herbin et al., 1987; MagniezJannin and Muller, 1987; Koutsoukos et al., 1991; Hart and Koutsoukos, 2015). Bolli et al. (1978) reported laminated limestones and black shales in the late Aptian-early Albian interval of the DSDP 364 site in Kwanza Basin, interpreted as a high bioproductivity stage under euxinic conditions. Herbin et al. (1987) revisited this interval and showed TOC contents up to $29 \%$ and $\mathrm{HI}$ values of $800 \mathrm{mgHC} / \mathrm{gTOC}$ associated with an absence of benthic foraminifers (Magniez-Jannin and Muller, 1987), assigning it to the early-middle Albian. These authors endorsed that anoxic conditions were a prevailing feature of the South Atlantic at this time, and suggested that organic-rich sediments deposited from the late Jurassic to the early Albian were associated with the "OAE 1". Koutsoukos et al. (1991) also attributed the organic-rich deposits (TOC from 2 to 12\%; HI up to $709 \mathrm{mgHC} / \mathrm{gTOC}$ ) of the upper Aptian-lower Albian interval of the Sergipe Basin (NE Brazil) to a high productivity under dysoxic conditions. However, although the authors considered a possible influence of the "OAE 1 ", they supported the interpretation that the local effects of a restricted circulation pattern ("silled basin" model; Schlanger and Jenkyns, 1976) in the early South Atlantic were the dominant cause in organicmatter preservation. Hart and Koutsoukos (2015) maintained this interpretation.

In turn, Jenkyns (2010) argued that in times of oceanic anoxic events, restricted settings might have achieved enhanced anoxic or even euxinic conditions, due to water stratification, such as reconstructed by Koutsoukos et al. (1991) for the South Atlantic's early marine phases. The restricted setting could explain the homogeneous sedimentary succession, represented by the highfrequency intercalations of shales and organic-rich limestones within unit III (Fig. 10), similar to the upper Aptian-early Albian interval described from DSDP site 364 (Bolli et al., 1978; Herbin et al., 1987; Kochhann et al., 2013). We argue that if the organicrich deposits of the early central South Atlantic were the result of the restricted circulation patterns only, they would be observed until the middle-late Albian, when open-marine conditions were developed (Bengtson et al., 2007), which is not the case. Besides similar isotopic trends between CD-1 and OAE 1b set (Fig. 14), this supports the interpretation that a global forcing influenced the deposition of these organic-rich limestones, in times of increased greenhouse, continental runoff and high productivity. This scenario matches the paleoenvironmental evolution proposed for the unit III.

Therefore, we interpret that global conditions were determining on the deposition of the early marine organic-rich deposits of the South Atlantic Ocean through late Aptian-early Aptian transition. The global driving forces would have played the primary role in the organic-matter deposition, although the depositional facies are particular to the restricted primitive South Atlantic. The association between these deposits and the major global changes related to $\mathrm{OAE} 1 \mathrm{~b}$ is possible due to the isotope signatures, mainly the rapid increase in ${ }^{87} \mathrm{Sr} /{ }^{86} \mathrm{Sr}$ ratios, as a remarkable feature in the $\mathrm{Sr}$ isotope evolution of Cretaceous seawater (Bralower et al., 1997; McArthur et al., 2012). For further higher-resolution stratigraphic correlations between late Aptian-early Albian South Atlantic and Tethyan sections, and the possible identification of OAE 1b specific levels, detailed biostratigraphic studies are needed. However, these deposits can only be investigated from offshore petroleum well data, which in most cases do not provide the proper samples and sufficient resolution for these purposes.

\section{Conclusions}

The CD-1 section provided unprecedented data of the distal facies of the early marine South Atlantic. The microfacies associations of the basal unit I (MA-1 and MA-2), benthic-dominated, were attributed to the proximal portions of the carbonate ramp, in a low to moderate energy environment, oxygenated bottom conditions, and low TOC contents. Carbonate microfacies associations of unit III (MA-3, MA-4 and MA-5) are interbedded with shales and presented a planktic-dominated fauna, representing the more distal regions of the early South Atlantic. Increased TOC contents and the lack of benthic organisms suggested oxygen-depletion and favourable conditions for organic-matter preservation during unit III, although well-oxygenated microfacies also presented substantial TOC amounts ( $>0.5 \%$ ). This suggests that redox conditions may not have played the main role in this event.

The occurrence of Colomiella recta in unit III limits the studied section to the latest late Aptian-early Albian, which is supported by the correlation of the increasing trend of ${ }^{87} \mathrm{Sr} /{ }^{86} \mathrm{Sr}$ ratios and the long-term $\delta^{13} \mathrm{C}_{\text {carb }}$ negative excursion with respective reference curves (e.g. Bodin et al., 2015). Increased TOC contents, the drastic increase in ${ }^{87} \mathrm{Sr} /{ }^{86} \mathrm{Sr}$ ratios $(0.7072-0.7074)$, and terrigenous input to the top of unit III, as well as inferences of high productivity, are compatible to the scenario of the major perturbations related to OAE $1 \mathrm{~b}$ and Aptian-Albian transition. At this time, an enhanced greenhouse stage led to increases in chemical weathering, nutrient influx, bioproductivity, and consequent deposition of organic-rich sediments. Therefore, the present study proposed the influence of the global ocean-climate events through late Aptian-early Albian transition on the deposition of the organic-rich limestones of unit III. This reinforces that this interval was marked by drastic major changes in the ocean-climate system, also recorded on the deposits of the primitive South Atlantic Ocean. Further biostratigraphic and chemostratigraphic studies in higher resolution are needed to elucidate the possible correlation between the early South Atlantic organic-rich deposits and OAE 1b levels. 


\section{Acknowledgements}

This study was funded by the project "Carbonate rocks of the Cretaceous of Brazil", a partnership between UNESP and PETROBRAS. The authors would like to thank the staff of Center for Petroleum Geosciences - UNESPetro and Geochemistry Laboratory of Petrology and Metallogeny Department, São Paulo State University (UNESP); Chemical Stratigraphy and Organic Geochemistry Laboratory, Rio de Janeiro State University; and Center of Geochronological Research (CPGeo), University of São Paulo (USP); for supporting data acquisition. We also want to thank to Sylvia dos Anjos, Rogério Antunes, and Adali Spadini (PETROBRAS) for supporting this study, to Christiano $\mathrm{Ng}$ for revision of the microfacies data, and to Gustavo M. de Paula-Santos for all the revision and suggestions made. Finally, we are grateful to the associate editor Dr. Peter Harries and the two anonymous reviewers for the constructive comments and suggestions that improved this manuscript.

\section{References}

Antunes, R.L., 1996. Biozonas de nanofósseis do Cretáceo da Margem Continental Brasileira: problemas e possíveis soluções. Boletim de Geociências da Petrobras $10(1 / 4), 19-42$.

Arai, M., 2014. Aptian/Albian (Early Cretaceous) paleogeography of the South Atlantic: a paleontological perspective. Brazilian Journal of Geology 44 (2), $339-350$.

Azevedo, R.L.M., 2004. Paleoceanografia e a evolução do Atlântico Sul no Albiano. Boletim de Geociências da Petrobras 12 (2), 231-249.

Azevedo, R.L.M., Gomide, J., Viviers, M.C., 1987a. Geo-história da Bacia de Campos, Brasil: do Albiano ao Maastrichtiano. Revista Brasileira de Geociências 17 (2), 139-146.

Azevedo, R.L.M., Gomide, J., Viviers, M.C., Hashimoto, A.T., 1987b. Bioestratigrafia do Cretáceo marinho da Bacia de Campos, Brasil. Revista Brasileira de Geociências 17 (2), 147-153.

Banner, J.L., 1995. Application of the isotope and trace element geochemistry of strontium to studies of diagenesis in carbonate systems. Sedimentology 42 $805-824$.

Banner, J.L., 2004. Radiogenic isotopes: systematics and applications to earth surface processes and chemical stratigraphy. Earth-Science Reviews 65, 141-194.

Banner, J.L., Hanson, G., 1990. Calculation of simultaneous isotopic and trace element variations during water-rock interaction with applications to carbonate diagenesis. Geochimica et Cosmochimica Acta 54, 3123-3137.

Bengtson, P., Koutsoukos, E.A.M., Kakabadze, M.V., Zucon, M.H., 2007. Ammonite and foraminiferal biogeography and the opening of the equatorial Atlantic gateway. In: 1er Symposium International de Paléobiogéographie, Paris, p. 12. Abstracts.

Birgel, D., Meister, P., Lundberg, R., Horath, T.D., Bontognali, T.R.R., Bahniuk, A.M. Rezende, C.E., Vasconcelos, C., McKenzie, J.A., 2015. Methanogenesis produces strong ${ }^{13} \mathrm{C}$ enrichment in stromatolites of Lagoa Salgada, Brazil: a modern analogue for Paleo-/Neoproterozoic stromatolites? Geobiology 13, 245-266.

Blanco-Bustamante, S., 2001. Biocronologia del Cretacico medio de Cuba Central de acuerdo a microfosiles planctonicos: su relacion con el paleoambiente. In: IV Congresso de Geologia y Mineria, Estratigrafía, Paleontología y Sedimentología, La Habana. Memorias Geomin, pp. 31-39.

Bodin, S., Meissner, P., Janssen, N.M.M., Steuber, T., Mutterlose, J., 2015. Large igneous provinces and organic carbon burial: Controls on global temperature and continental weathering during the Early Cretaceous. Global and Planetary Change 133, 238-253. http://dx.doi.org/10.1016/j.gloplacha.2015.09.001.

Bolli, H.M., Ryan, W.B.F., Foresman, J.B., Hottman, W.E., Kagami, H., Longoria, J.F. Mcknight, B.K., Melguem, M., Natland, J., Proto-Decima, F., Siesser, W.G., 1978. Angola continental margin - sites 364 and 365. In: Bolli, H.M., Ryan, W.B.F. et al. (Eds.), Initial Reports of the Deep Sea Drilling Project, 40. United States Government Printing Office, Washington D.C., USA, pp. 357-455.

Bralower, T.J., Fullagar, P.D., Paull, C.K., Dwyer, G.S., Leckie, R.M., 1997. Mid-Cretaceous strontium-isotope stratigraphy of deep-sea sections. Geological Society of America Bulletin 109 (10), 1421-1442.

Brand, U., Veizer, J., 1980. Chemical diagenesis of a multicomponent carbonate system-1: trace elements. Journal of Sedimentary Petrology 50, 1219-1236.

Browning, E.L., Watkins, D.K., 2008. Elevated primary productivity of calcareous nannoplankton associated with ocean anoxic event 1b during the Aptian/Albian transition (Early Cretaceous). Paleoceanography 23, PA2213,. http://dx.doi.org/ 10.1029/2007PA001413.

Caron, C., 1978. Cretaceous Planktonic Foraminifers from DSDP Leg 40, Southeastern Atlantic Ocean. In: Bolli, H.M., Ryan, W.B.F., et al. (Eds.), Initial Reports of the Deep Sea Drilling Project, 40. United States Government Printing Office, Washington D.C., USA, pp. 651-678.

Carvalho, M.D., Dias-Brito, D., Ferré, B., 1999. Bacia de Jequitinhonha - novas indicações de águas tetianas no Atlântico Sul. In: Boletim do $5^{\circ}$ Simpósio do Cretáceo do Brasil, Rio Claro, Brazil, pp. 643-649.
Chang, H.K., Kowsmann, R.O., 1987. Interpretação genética das sequências estratigráficas das bacias da margem continental brasileira. Revista Brasileira de Geociências 17 (2), 74-80.

Chevalier, J., Fischer, M., 1982. Présence de Colomiella Bonet (Calpionellidea) dans le Crétace inférieur (Madiéla) du Gabon. Cahiers de Micropaléontologie 2, 29-34.

Chihaoui, A., Jaillard, E., Latil, J.L., Zghal, I., Susperregui, A.S., Touir, J., Ouali, J., 2010. Stratigraphy of the Hameima and lower Fahdene Formations in the Tadjerouine area (Northern Tunisia). Journal of African Earth Sciences 58, 387-399.

Coccioni, R., Sabatino, N., Frontalini, F., Gardin, S., Sideri, M., Sprovieri, M., 2014. The neglected history of Oceanic Anoxic Event 1b: insights and new data from the Poggio le Guaine section (Umbria-Marche Basin). Stratigraphy 11, 245-282.

Dias-Brito, D., 1987. A Bacia de Campos no Mesocretáceo: uma contribuição à paleoceanografia do Atlântico Sul Primitivo. Revista Brasileira de Geociências 17 (2), 162-167.

Dias-Brito, D., 1994. Comparação dos carbonatos pelágicos do Cretáceo médio da Margem Atlântica Brasileira com os do Golfo do México: novas evidências do Tétis Sul-Atlantiano. In: Boletim do 3 Simpósio sobre o Cretáceo do Brasil, Rio Claro, Brazil, pp. 11-18.

Dias-Brito, D., 1995. Calcisferas e microfácies em rochas carbonáticas pelágicas mesocretáceas (Doctorate thesis). Universidade Federal do Rio Grande do Sul, Porto Alegre, Brazil, 688 pp.

Dias-Brito, D., 1999. Usando pitonelidos e colomielidos para dividir o Albiano: um estudo a partir da margem sudeste do Brasil. In: Boletim do 5 Simpósio sobre o Cretáceo do Brasil, Rio Claro, Brazil, pp. 627-635.

Dias-Brito, D., 2000. Global stratigraphy, palaeobiogeography and palaeoecology of Albian-Maastrichtian pithonellid calcispheres: impact on Tethys configuration. Cretaceous Research 21 (2-3), 315-349.

Dias-Brito, D., 2002. Registros de calpionelidos no Cretáceo do Atlantico Sul: significado paleoceanográfico e implicações. In: Boletim do $6^{\circ}$ Simpósio sobre o Cretáceo do Brasil $/ 2^{\circ}$ Simpósio sobre el Cretacico de América del Sur, São Pedro, Brazil, pp. 311-316.

Dias-Brito, D. Azevedo, R.L.M. 1986. As sequências deposicionais marinhas da Bacia de Campos sob a ótica paleoecológica. In: Congresso Brasileiro de Geologia 34, pp. 38-48. Goiânia, Brazil. Anais 1.

Dias-Brito, D., Ferré, B., 2001. Roveacrinids (stemless crinoids) in the Albian carbonates of the offshore Santos Basin, southeastern Brazil: stratigraphic, palaeobiogeographic and palaeoceanographic significance. Journal of South American Earth Sciences 14 (2), 203-218.

Erbacher, J., Hemleben, C., Huber, B.T., Markey, M., 1999. Correlating environmental changes during early Albian oceanic anoxic event 1B using benthic foraminiferal paleoecology. Marine Micropaleontology 38, 7-28.

Erbacher, J., Huber, B.T., Norris, R.D., Markey, M., 2001. Increased thermohaline stratification as a possible cause for an ocean anoxic event in the Cretaceous period. Nature 409, 325-327.

Esteves, F.R., Spadini, A.R., Saito, M., 1987. A sedimentação Albo-Turoniana (Formação Macaé) da Bacia de Campos. In: Simpósio de Geologia Regional 1, Rio de Janeiro, Brazil, pp. 27-42. Anais.

Faure, G., Mensing, T.M., 2005. The Rb-Sr method. In: Isotopes - Principles and Applications, third ed. John Wiley and Sons, Hoboken, New Jersey, USA, pp. 75-112.

Favoreto, J., Rohn, R., Lykawka, R., Okubo, J., 2016. Caracterização sedimentológica dos carbonatos albianos do reservatório Quissamã na porção meridional da Bacia de Campos. Geociências 35 (1) 1-15.

Föllmi, K.B., 2012. Early Cretaceous life, climate and anoxia. Cretaceous Research 35, $230-257$.

Föllmi, K.B., Godet, A., Bodin, S., Linder, P., 2006. Interactions between environmental change and shallow water carbonate buildup along the northern Tethyan margin and their impact on the Early Cretaceous carbon isotope record. Paleoceanography 21, PA4211,. http://dx.doi.org/10.1029/2006PA001313.

Gale, A.S., Bown, P. Caron, M., Crampton, J., Crowhurst, S.J., Kennedy, W.J., Petrizzo, M.R., Wray, D.S., 2011. The uppermost middle and upper Albian succession at the Col de Palluel, Hautes-Alpes, France: an integrated study (ammonites, inoceramid bivalves, planktonic foraminifera, nannofossils, geochemistry, stable oxygen and carbon isotopes, cyclostratigraphy). Cretaceous Research 32, 59-130.

González-León, C.M., Scott, R.W., Löser, H., Lawton, T.F., Robert, E., Valencia, V.A., 2008. Upper Aptian - lower Albian Mural Formation: stratigraphy, biostratigraphy and depositional cycles on the Sonoran shelf, northern Mexico. Cretaceous Research 29, 249-266.

Gradstein, F.M., Ogg, J.G., Schmitz, M.D., Ogg, G.M., 2012. The Geologic Time Scale 2012. Elsevier, Oxford, 1144 pp.

Gradstein, F.M., Ogg, J.G., Smith, A.G., 2004. A Geologic Time Scale 2004. Cambridge University Press, Cambridge, $589 \mathrm{pp}$

Guardado, L.R., Gamboa, L.A.P., Luchesi, C.F. 1989. Petroleum geology of the Campos Basin, a model for a producing Atlantic type basin. In: Edwards, J.D., Santogrossi, P.A. (Eds.), Divergent/Passive Margin Basins, American Association of Petroleum Geologists Memoir, Tulsa 48, pp. 3-79.

Hart, M.B., Koutsoukos, E.A.M., 2015. Paleoecology of Cretaceous Foraminifera: examples from the Atlantic Ocean and Gulf of Mexico Region. Gulf Coast Association of Geological Societies Transactions 65, 175-199.

Herbin, J.P., Muller, C., Graciansky, P.C., Jacquin, T., Magniez-Jannin, F., Unternehr, P., 1987. Cretaceous anoxic events in the South Atlantic. Revista Brasileira de Geociências 17 (2), 92-99. 
Herrle, J.O., Köbler, P., Friedrich, O., Erlenkeuser, H., Hemleben, C., 2004. High-resolution carbon isotope records of the Aptian to Lower Albian from SE France and the Mazagan Plateau (DSDP Site 545): a stratigraphic tool for paleoceanographic and paleobiologic reconstruction. Earth and Planetary Science Letters 218, 149-161.

Herrle, J.O., Schröder-Adams, C.J., Davis, W., Pugh, A.T., Galloway, J.M., Fath, J., 2015. Mid-cretaceous high arctic stratigraphy, climate and oceanic anoxic events. Geology. http://dx.doi.org/10.1130/G36439.1.

Huber, B.T., Leckie, R.M., 2011. Planktic foraminiferal species turnover across deepsea Aptian/Albian boundary sections. Journal of Foraminiferal Research 41, 53-95.

Huber, B.T., MacLeod, K.G., Gröcke, D.R., Kucera, M., 2011. Paleotemperature and paleosalinity inferences and chemostratigraphy across the Aptian/Albian boundary in the subtropical North Atlantic. Paleoceanography 26, PA4221,. http://dx.doi.org/10.1029/2011PA002178.

Hudson, J.D., 1977. Stable isotopes and limestone lithification. Journal of Geological Society 133 (6), 637-660.

Jenkyns, H.C., 2010. Geochemistry of oceanic anoxic events. Geochemistry, Geophysics, Geosystems 11 (3), 30 pp.

Jones, C.E., Jenkyns, H.C., 2001. Seawater strontium isotopes, oceanic anoxic events, and seafloor hydrothermal activity in the Jurassic and Cretaceous. American Journal of Science 301, 112-149.

Kah, L.C., 2000. Depositional $\delta^{18} \mathrm{O}$ signatures in Proterozoic dolostones: constraints on seawater chemistry and early diagenesis. In: Grotzinger, J.P., James, N.P. (Eds.), Carbonate Sedimentation and Diagenesis in the Evolving Precambrian World, SEPM, Society for Sedimentary Geology, Special Publication 67, pp. 345-360.

Kennedy, W.J., Gale, A.S., Huber, B.T., Petrizzo, M.R., Bown, P., Barchetta, A., Jenkyns, H.C., 2014. Integrated stratigraphy across the Aptian/Albian boundary at Col de Pré- Guittard (southeast France): a candidate Global Boundary Stratotype Section. Cretaceous Research 51, 248-259.

Kochhann, K.G.D., Koutsoukos, E.A.M., Fauth, G., Sial, A.N., 2013. Aptian-Albian planktic foraminífera from DSDP 364 (Offshore Angola): bioestratigraphy, paleoecology and paleoceanographic significance. Journal of Foraminiferal Research 43 (4), 443-463.

Koutsoukos, E.A.M., 1992. Late Aptian to Maastrichtian foraminiferal biogeography and palaeoceanography of the Sergipe Basin, Brazil. Palaeogeography, Palaeoclimatology, Palaeoecology 92, 295-324.

Koutsoukos, E.A.M., Dias-Brito, D., 1987. Paleobatimetria da margem continental do Brasil durante o Albiano. Revista Brasileira de Geociências 17 (2), 86-91.

Koutsoukos, E.A.M., Mello, M.R., Azambuja Filho, N.C., Hart, M.B., Maxwell, J.R., 1991 The Upper Aptian-Albian succession of the Sergipe Basin, Brazil: an integrated paleoenvironmental assessment. American Association of Petroleum Geologists Bulletin 75, 479-498.

Leckie, R.M., Bralower, T.J., Cashman, R., 2002. Oceanic anoxic events and plankton evolution: biotic response to tectonic forcing during the mid-Cretaceous. Paleoceanography 17 (3). http://dx.doi.org/10.1029/2001PA000623.

Longoria, J.F., 1984. Cretaceous biochronology from the Gulf of Mexico region based on planktonic microfossils. Micropaleontology 30 (3), 225-242.

Longoria, J.F., Monreal, R., 2009. The use of planktonic microfossils to resolve chronostratigraphic, tectonic, and paleogeographic uncertainties in the Lower Cretaceous of eastern Sonora, NW Mexico. In: Geologic Problem Solving with Microfossils: A Volume in Honor of Garry D. Jones. SEPM Special Publication 93, pp. $269-285$.

Madhavaraju, J., Sial, A.N., González-León, C.M., Nagarajan, R., 2013. Carbon and oxygen isotopic variations in early Albian limestone facies of the Mural Formation, Pitaycachi section, northeastern Sonora, Mexico. Revista Mexicana de Ciências Geológicas 30, 526-539.

Magniez-Jannin, F., Muller, C., 1987. Cretaceous stratigraphic and paleoenvironmental data from the South Atlantic (foraminifers and nannoplankton). Revista Brasileira Geociências 17 (2), 100-105.

McArthur, J.M., Howarth, R.J., Shields, G.A., 2012. Strontium isotope stratigraphy. In: Gradstein, F.M., Ogg, J.M., Schmitz, M.D., Ogg, G.M. (Eds.), The Geologic Time Scale, 1. Elsevier, pp. 127-144.

Meister, P., Gutjahr, M., Frank, M., Bernasconi, S.M., Vasconcelos, C., McKenzie, J.A., 2011. Dolomite formation within the methanogenic zone induced by tectonically driven fluids in the Peru accretionary prism. Geology 39 (6), 563-566. http://dx.doi.org/10.1130/G31810.1.

Michalík, J., Lintnerová, O., Reháková, D., Boorová, D., Simo, V., 2012. Early Cretaceous sedimentary evolution of a pelagic basin margin (the Manín Unit, central Western Carpathians, Slovakia). Cretaceous Research 38, 68-79.

Mohriak, W.U., 2004. Recursos energéticos associados à ativação tectônica mesozoico-cenozoica da America do sul. In: Mantesso-Neto, V., Bartorelli, A. Carneiro, C.D.R., Brito-Neves, B.B. (Eds.), Geologia do continente sulamericano: evolução da obra de Fernando Flávio Marques de Almeida, pp. 293-318. Beca, São Paulo.

Mohriak, W.U., 2009. Tectônica de sal autóctone e alóctone na margem sudeste brasileira. In: Mohriak, W.U., Szatmari, P., Anjos, S.M.C. (Eds.), Sal: Geologia e Tectônica, pp. 302-315. Beca, São Paulo.

Morrow, D.W., Mayers, I.R., 1978. Simulation of limestone diagenesis - a model based on strontium depletion. Canadian Journal of Earth Sciences 15, 376-396. Moullade, M., Guérin, S., 1982. Le probleme des relations de l'Atlantique Sud et de l'Atlantique Central au Cretacé moyen: nouvelles donnés microfuniques d'après les forages D.S.D.P. Bulletin de la Societe Geologique de France 24 (3), $511-517$.

Núñez-Useche, F., Barragán, R., 2012. Microfacies analysis and paleoenvironmental dynamic of the Barremian-Albian interval in Sierra del Rosario, eastern Durango state, Mexico. Revista Mexicana de Ciencias Geológicas 29 (1), 204-218.

Núñez-Useche, F., Barragán, R., Canet, C., López-Martínez, R., 2016. Record of upper Aptian - lower Albian environmental perturbation in northeastern Mexico. Journal of South American Earth Sciences 70, 298-307.

Ojeda, H.A.O., 1982. Structural framework, stratigraphy and evolution of Brazilian Marginal Basins. American Association of Petroleum Geologists Bulletin 66 (6), $732-749$.

Okubo, J., Lykawka, R., Warren, L.V., Favoreto, J., Dias-Brito, D., 2015. Depositional diagenetic and stratigraphic aspects of Macaé Group carbonates (Albian): example from an oilfield from Campos Basin. Brazilian Journal of Geology 45 (2), 243-258.

Palmer, M.R., Edmond, J.M., 1992. Controls over the strontium isotope composition of river water. Geochimica et Cosmochimica Acta 56, 2099-2111.

Petrizzo, M.R., Huber, B.T., Gale, A.S., Barchetta, A., Jenkyns, H.C., 2012. Abrupt planktic foraminiferal turnover across the Niveau Kilian at Col de Pré-Guittard (Vocontian Basin, southeast France): new criteria for defining the Aptian/Albian boundary. Newsletter on Stratigraphy 45 (1), 55-74.

Ponte, F.C., Asmus, H., 2004. As bacias marginais brasileiras: estágio atual de conhecimento. Boletim de Geociências da Petrobrás 12 (2), 385-420.

Premoli-Silva, I., Mcnulty, C.L., 1984. Planktonic foraminifers and calpionellids from Gulf of Mexico sites, Deep Sea Drilling Project leg 77. In: Buffler, R.T., Schlager, W. (Eds.), Initial Reports of DSDP 77. U.S. Government Printing Office, Washington, USA, pp. 547-584.

Reimann, C., Caritat, P., 1998. Chemical Elements in the Environment. Factsheets for the Geochemist and Environmental Scientist. Springer, Berlin, 398 pp.

Renard, M., 1986. Pelagic carbonate chemostratigraphy (Sr, Mg, O-18, C-13). Marine Micropaleontology 10, 117-164.

Sabatino, N., Coccioni, R., Manta, D.S., Baudin, F., Vallefuoco, M., Traina, A., Sprovieri, M., 2015. High-resolution chemostratigraphy of the late Aptian-early Albian oceanic anoxic event (OAE 1b) from the Poggio le Guaine section (Umbria-Marche Basin, central Italy). Palaeogeography, Palaeoclimatology, Palaeoecology 426, 319-333.

Schaller, H., 1973. Presença do Nannofóssil Nannoconus truitti Brönnimann determina idade albiana/cenomaniana para a Formação Macaé. Estratigrafia da Bacia de Campos. In: XXVII Congresso Brasileiro de Geologia, Aracaju, Brazil, pp. 247-258. Anais.

Schlanger, S.O., Jenkyns, H.C., 1976. Cretaceous anoxic events: causes and consequences. Geologie En Mijnbouw 55, 179-184.

Scholle, P.A., Arthur, M.A., 1980. Carbon isotopic fluctuations in Cretaceous pelagic limestones: potential stratigraphic and petroleum exploration tool. American Association of Petroleum Geologists Bulletin 64 (1), 67-87.

Spadini, A.R., Esteves, F.R., Dias-Brito, D., Azevedo, R.L.M., Rodrigues, R., 1988. The Macaé Formation, Campos Basin, Brazil: its evolution in the context of the initial history of the South Atlantic. Revista Brasileira de Geociências 18 (3), $261-272$.

Tissot, B.P., Welte, D.H., 1984. Petroleum Formation and Occurrence, second ed. Springer-Verlag, Berlin, Germany, p. 699.

Trabucho-Alexandre, J., Van Gilst, R.I., Rodríguez-López, J.P., De Boer, P.L., 2011. The sedimentary expression of Oceanic Anoxic Event 1b in the North Atlantic. Sedimentology 58, 1217-1246.

Trejo, M., 1975. Tintinidos mesozoicos de Mexico (taxonomia y datos paleobiológicos). Boletin Asociacion Mexicana de Geologos Petroleros 27 (10-12), 329-449.

Tröelsen, J.C., Quadros, L.P., 1971. Distribuição bioestratigráfica dos nanofósseis em sedimentos marinos (Aptiano-Mioceno) do Brasil. Anais da Academia Brasileira de Ciências, Rio de Janeiro 43, 577-609.

Veizer, J., 1978. Simulation of limestone diagenesis - a model based on strontium depletion: Discussion. Canadian Journal of Earth Sciences 15, 1683-1685.

Veizer, J., 1983. Chemical diagenesis of carbonates: theory and application of trace element technique. In: Arthur, M.A., Anderson, T.F., Kaplan, I.R., Veizer, J., Land, L.S. (Eds.), Stable Isotopes in Sedimentary Geology, Society of Economic Paleontologists and Mineralogists Short Course Notes, Tulsa, 10, pp. 3.1-3.100.

Veizer, J., Ala, D., Azmy, K., Bruckschen, P., Buhl, D., Bruhn, F., Carden, G.A.F. Diener, A., Ebneth, S., Godderis, Y., Jasper, T., Korte, C., Pawellek, F., Podlaha, O.G., Strauss, H., 1999. ${ }^{87} \mathrm{Sr} /{ }^{86} \mathrm{Sr}, \delta^{13} \mathrm{C}$ and $\delta^{18} \mathrm{O}$ evolution of Phanerozoic seawater. Chemical Geology 161, 59-88.

Vincent, B., Van Buchem, F.S.P., Bulot, L.G., Immenhauser, A., Caron, M., Baghbani, D. Huc, A.Y., 2010. Carbon-isotope stratigraphy, biostratigraphy and organic matter distribution in the Aptian - Lower Albian successions of southwest Iran (Dariyan and Kazhdumi formations). GeoArabia Special Publication 4 (1), 139-197.

Viviers, M.C., Azevedo, R.L.M., 1988. The southeastern area of the brazilian continental margin: its evolution during the middle and late Cretaceous as indicated by paleoecological data. Revista Brasileira de Geociências 18 (3), 291-298.

Winter, W.R., Jahnert, R.J., França, A.B., 2007. Bacia de Campos. Boletim de Geociências da Petrobrás 15 (2), 511-529. 